\title{
Allylpalladium Complexes of Mixed-Donor Diphosphazane Ligands Bearing a Stereogenic Phosphorus Centre: Structure and Stereodynamics
}

\author{
Swadhin K. Mandal, ${ }^{[a]}$ G. A. Nagana Gowda, ${ }^{[b]}$ Setharampattu S. Krishnamurthy, ${ }^{*[a]}$ \\ Chong Zheng, ${ }^{[c]}$ Shoujian Li, ${ }^{[\mathrm{cl}}$ and Narayan S. Hosmane ${ }^{[\mathrm{cl}}$
}

Keywords: Allyl complexes / P ligands / Palladium / N ligands

( $\eta^{3}$-Allyl)palladium complexes of general formula $\left[\operatorname{Pd}\left(\eta^{3}\right.\right.$ $\left.\left.\mathrm{R}^{\prime} \mathrm{C}_{3} \mathrm{H}_{4}\right)\left\{\eta^{2}-\mathrm{Ph}_{2} \mathrm{PN}(\mathrm{R}) \mathrm{PPh}\left(\mathrm{N}_{2} \mathrm{C}_{3} \mathrm{HMe}_{2}-3,5\right)\right\}\right]\left(\mathrm{PF}_{6}\right) \quad$ (3-6) and $\left[\mathrm{Pd}\left(\eta^{3}-\mathrm{R}^{\prime} \mathrm{C}_{3} \mathrm{H}_{4}\right)\left\{\eta^{2}-\mathrm{Ph}_{2} \mathrm{P}(\mathrm{S}) \mathrm{N}\left(\mathrm{CHMe}_{2}\right) \mathrm{PPh}\left(\mathrm{N}_{2} \mathrm{C}_{3} \mathrm{HMe}_{2}-3,5\right)\right\}\right]-$ $\left(\mathrm{PF}_{6}\right)$ (7-8), containing pyrazolyl-substituted diphosphazane ligands bearing a stereogenic phosphorus centre, have been synthesised. NMR spectroscopic and X-ray diffraction studies showed that the diphosphazane ligand in $\left[\operatorname{Pd}\left(\eta^{3}\right.\right.$ $\left.\left.\mathrm{R}^{\prime} \mathrm{C}_{3} \mathrm{H}_{4}\right)\left\{\eta^{2}-\mathrm{Ph}_{2} \mathrm{PN}(\mathrm{R}) \mathrm{PPh}\left(\mathrm{N}_{2} \mathrm{C}_{3} \mathrm{HMe}_{2}-3,5\right)\right\}\right]\left(\mathrm{PF}_{6}\right)\left[\mathrm{R}^{\prime}=\mathrm{Me}\right.$ or $\mathrm{Ph}_{i} \mathrm{R}=\mathrm{CHMe}_{2}$ (3 and 5) or $(S)-{ }^{*} \mathrm{CHMePh}$ (4 and 6)] displayed unprecedented $P, N$-coordination instead of the hitherto observed $P, P$-coordination. These complexes existed in solution as mixtures of endo,syn,trans, exo,syn,trans, and endo,syn,cis diastereomers. In the solid state, only the endo,syn,trans isomer was observed for complex 5. Phasesensitive 2-D NOESY and ROESY spectra showed that the complexes 3-5 underwent syn, anti isomerisation; the NMR spectroscopic data were consistent with a mechanism involving the opening of the $\eta^{3}$-allyl group at the trans position with respect to the phosphorus centre. The isomerisation thus appeared to be electronically controlled. The complexes $\left[\mathrm{Pd}\left(\eta^{3}-\mathrm{MeC}_{3} \mathrm{H}_{4}\right)\left\{\eta^{2}-\mathrm{Ph}_{2} \mathrm{P}(\mathrm{S}) \mathrm{N}\left(\mathrm{CHMe}_{2}\right) \mathrm{PPh}\left(\mathrm{N}_{2} \mathrm{C}_{3} \mathrm{HMe}_{2}-\right.\right.\right.$ $3,5)\}]\left(\mathrm{PF}_{6}\right) \quad(7)$ and $\left[\mathrm{Pd}\left(\eta^{3}-\mathrm{PhC}_{3} \mathrm{H}_{4}\right)\left\{\eta^{2}-\mathrm{Ph}_{2} \mathrm{P}(\mathrm{S}) \mathrm{N}\left(\mathrm{CHMe}_{2}\right)-\right.\right.$ $\left.\left.\mathrm{PPh}\left(\mathrm{N}_{2} \mathrm{C}_{3} \mathrm{HMe}_{2}-3,5\right)\right\}\right]\left(\mathrm{PF}_{6}\right)(\mathbf{8})$, bearing the diphosphazane monosulfide $\mathrm{Ph}_{2} \mathrm{P}(\mathrm{S}) \mathrm{N}\left(\mathrm{CHMe}_{2}\right) \mathrm{PPh}\left(\mathrm{N}_{2} \mathrm{C}_{3} \mathrm{HMe}_{2}-3,5\right)$ (1c), displayed $P, S$-coordination and existed in solution as six and four isomers, respectively. Exchange was observed among four of the six isomers of $\mathbf{7}$ and among all the four isomers of 8 at 298 K, through the opening of the $\eta^{3}$-allyl moiety, which appeared to be subject to both electronic and steric control.

(C) Wiley-VCH Verlag GmbH, 69451 Weinheim, Germany, 2002)

\section{Introduction}

Palladium-catalysed allylic substitution reactions have emerged as a powerful methodology in organic synthesis; ${ }^{[1]}$ the use of chiral auxiliary ligands can result in the formation of optically active products. Initially, chiral diphosphane ligands were predominantly used, while in recent years, asymmetric mixed-donor ligands have proven to be advantageous. The use of $\mathrm{P}, \mathrm{N}-,{ }^{[2]} \mathrm{P}, \mathrm{S}-,{ }^{[3]}$ and $\mathrm{S}, \mathrm{N}-$ donor $^{[4]} \mathrm{li}-$ gands in particular has resulted in high enantiomeric excesses in allylic alkylation reactions, which is attributed to the electronic effects of two different donor centres present in these ligand systems. In contrast to most other transition metal catalysed reactions, palladium-catalysed allylic alkylations do not rely solely on a single mechanism as a source of asymmetry. ${ }^{[5]}$ Differentiation of the enantiotopic

[a] Department of Inorganic and Physical Chemistry, Indian Institute of Science,

Bangalore 560012, India

Fax: (internat.) + 91-80/360-0683 or -1552

E-mail: sskrish@ipc.iisc.ernet.in

[b] Sophisticated Instruments Facility, Indian Institute of Science, Bangalore 560012, India

[c] Department of Chemistry and Biochemistry, Northern Illinois University,

DeKalb, IL 60115, USA faces of a $\pi$-system is one possible mechanism, but the source of the enantioselectivity is complicated by the problems associated with the regioselectivity of nucleophilic attack, possibility of various configurational isomers, and the existence of several stereodynamic processes. ${ }^{[6]}$ The reaction proceeds through a ( $\pi$-allyl)palladium intermediate and the configuration of the organic product strongly depends on the nature of this intermediate. There is growing interest in understanding the solution structures and the dynamic solution behaviour of the chiral $\left(\eta^{3}\right.$-allyl)palladium intermediates, as these may be related to synthetic methods affording optically active products. ${ }^{[7]}$ The situation becomes even more complicated when both the auxiliary ligands and the allyl moiety are asymmetrical; in this case, various geometrical isomers with different allyl face coordination would result, as well as allylic arrangements. As a part of our ongoing investigations into the organometallic chemistry of diphosphazane ligands, ${ }^{[8-9]}$ we have recently begun a program of NMR studies of ( $\pi$-allyl)palladium complexes of diphosphazane and related ligand systems based on the $\mathrm{P}-\mathrm{N}-\mathrm{P}$ motif. The diphosphazane ligands display versatile transition metal organometallic chemistry ${ }^{[10]}$ and these ligand systems can be suitably modified, thus providing access to a range of mixed-donor ligands. Despite extensive studies of the reactions of diphosphazane ligands with sev- 
eral transition metal precursors, the allylpalladium chemistry of unsymmetrical diphosphazane ligands has not been explored except for a brief report on allylpalladium complexes of $\mathrm{Ph}_{2} \mathrm{PN}(\mathrm{H}) \mathrm{P}(\mathrm{O}) \mathrm{Ph}_{2} \cdot{ }^{[10 \mathrm{~d}]}$ Here we report the synthesis, solution characterisation and dynamic behaviour of $\left(\eta^{3}\right.$-allyl)palladium complexes bearing phosphorusstereogenic diphosphazane ligands $-\mathrm{Ph}_{2} \mathrm{PN}(\mathrm{R}) \mathrm{PPh}-$ $\left(\mathrm{N}_{2} \mathrm{C}_{3} \mathrm{HMe}_{2}-3,5\right)\left[\mathrm{R}=\mathrm{CHMe}_{2}(\mathbf{1 a})\right.$ or $\left.(S)-{ }^{*} \mathrm{CHMePh}(\mathbf{1 b})\right]$ - and the diphosphazane monosulfide ligand $\mathrm{Ph}_{2} \mathrm{P}(\mathrm{S}) \mathrm{N}\left(\mathrm{CHMe}_{2}\right) \mathrm{PPh}\left(\mathrm{N}_{2} \mathrm{C}_{3} \mathrm{HMe}_{2}-3,5\right)(\mathbf{c})$. In the case of $\mathbf{1 b}$, the $\left(S_{\mathrm{C}} R_{\mathrm{P}}\right)$ diastereomer, the absolute configuration of which has been determined by X-ray crystallography, ${ }^{[8 \mathrm{~d}]}$ was used for the preparation of allylpalladium complexes.

\section{Results and Discussion}

\section{Synthesis}

The cationic allyl complexes $\mathbf{3}-\mathbf{8}$ were prepared by treatment of the chloro-bridged allylpalladium dimer $\mathbf{2}$ with the appropriate ligands in the presence of $\mathrm{NH}_{4} \mathrm{PF}_{6}$ in acetone (Scheme 1). These complexes have been characterised by elemental analyses and NMR spectroscopic data (see Exp. Sect.). Several isomers are possible for complexes that contain an unsymmetrically substituted allyl group. In the first place, isomers can arise because of different modes of coordination of the ligands (e.g., $P, P$ or $P, N$ for $\mathbf{1 a}$ or $\mathbf{1 b}, P, S$ or $P, N$ or $N, S$ for 1c). Secondly, geometrical isomers can be formed because the substituent on the allyl moiety can be oriented in a cis or trans position with respect to one of the phosphorus atoms. Thirdly, several allylic arrangements are also possible since the substituent on the allyl moiety can be positioned syn or anti with respect to the central allyl proton. Additionally, for each of these isomers, diastereomers can arise owing to the different face coordination (exo or endo) of the allyl group. The isomeric composition in each case was determined by NMR spectroscopy. The sali-

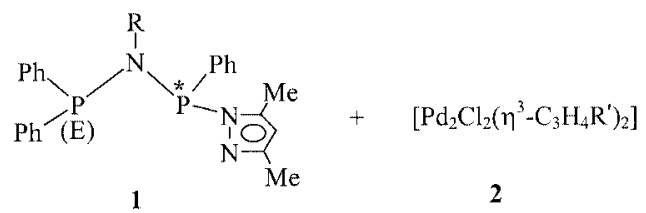

1a, $\mathrm{R}=\mathrm{CHMe}_{2}, \mathrm{E}=$ lone pair (1.p);

1b, $\mathrm{R}=(S)-{ }^{*} \mathrm{CHMePh}, \mathrm{E}=1 . \mathrm{p}$; $\left(S_{\mathrm{C}} R_{\mathrm{p}}\right.$ - diastereomer)

1c, $\mathrm{R}=\mathrm{CHMe}_{2}, \mathrm{E}=\mathrm{S}$

$$
\left[\mathrm{Pd}\left(\eta^{3}-\mathrm{C}_{3} \mathrm{H}_{4} \mathrm{R}^{\prime}\right)(1)\right]\left(\mathrm{PF}_{6}\right)
$$

\section{3-8}

3, $\mathrm{R}^{\prime}=\mathrm{Me}, \mathrm{R}=\mathrm{CHMe}_{2}, \mathrm{E}=1 . \mathrm{p}$;

4, $\mathrm{R}^{\prime}=\mathrm{Me}, \mathrm{R}=(S){ }^{*} \mathrm{CHMePh}, \mathrm{E}=1 . \mathrm{p}$;

5, $\mathrm{R}^{\prime}=\mathrm{Ph}, \mathrm{R}=\mathrm{CHMe}_{2}, \mathrm{E}=1 . \mathrm{p}$;

6, $\mathrm{R}^{\prime}=\mathrm{Ph}, \mathrm{R}=(S) *{ }^{*} \mathrm{CHMePh}, \mathrm{E}=1 . \mathrm{p}$;

$7, \mathrm{R}^{\prime}=\mathrm{Me}, \mathrm{R}=\mathrm{CHMe}_{2}, \mathrm{E}=\mathrm{S}$;

8. $\mathrm{R}^{\prime}=\mathrm{Ph}, \mathrm{R}=\mathrm{CHMe}_{2}, \mathrm{E}=\mathrm{S}$

Scheme 1 ent features of the spectroscopic data and dynamic behaviour are discussed below.

\section{NMR Studies on $\left[\operatorname{Pd}\left(\eta^{3}-\mathbf{R}^{\prime} \mathrm{C}_{3} \mathrm{H}_{4}\right)\left\{\boldsymbol{\eta}^{2}-\right.\right.$ $\left.\left.\mathrm{Ph}_{2} \mathrm{PN}(\mathrm{R}) \mathrm{PPh}\left(\mathrm{N}_{2} \mathrm{C}_{3} \mathrm{HMe}_{2}-3,5\right)\right\}\right]\left(\mathrm{PF}_{6}\right)(3-6)$}

The ${ }^{31} \mathrm{P}\left\{{ }^{1} \mathrm{H}\right\}$ NMR spectra of complexes $3-\mathbf{6}$ in $\mathrm{CDCl}_{3}$ in each case displayed six doublets (see Table 1) in different isomeric ratios, revealing the presence of three isomers. The structures proposed for these isomers are shown in Figure 1. Analysis of the ${ }^{13} \mathrm{C}$ NMR spectra of the allyl carbon nuclei pointed to $P, N$-coordination through the nitrogen atom at the 2-position of the pyrazole ring (see Table 2). The resonances of the central allyl carbon atoms of all the isomers appeared as doublets. For $P, P$-coordination, one should observe a doublet of doublets pattern in the ${ }^{13} \mathrm{C}$ NMR spectra for each of the palladium-bound allyl carbon nuclei. The signals for terminal allyl carbon nuclei appeared as two doublets and were assigned on the basis of the twobond phosphorus-carbon coupling and a $2-\mathrm{D}{ }^{13} \mathrm{C}-{ }^{1} \mathrm{H}$ HSQC experiment. The doublets in the ${ }^{13} \mathrm{C}$ NMR spectra in the $\delta=94-105$ and $78-80 \mathrm{ppm}$ ranges, with ${ }^{2} J_{\mathrm{P}, \mathrm{C}}$ values of $28-31 \mathrm{~Hz}$, were assigned to the substituted terminal allyl and unsubstituted terminal allyl carbon atom, respectively, trans to the coordinated phosphorus centre. On the other hand, the resonances for the substituted and unsubstituted terminal allyl carbon nuclei trans to the nitrogen atom appeared in more shielded regions $(\delta=64-77$ and

Table 1. The ${ }^{31} \mathrm{P}\left\{{ }^{1} \mathrm{H}\right\}$ NMR spectroscopic data for the complexes 3-8

\begin{tabular}{|c|c|c|c|c|}
\hline Complex ${ }^{[a]}$ & $\begin{array}{c}-\mathrm{PPh}\left(\mathrm{N}_{2} \mathrm{C}_{3} \mathrm{HMe}_{2}-3,5\right) \\
\left(\delta_{\mathrm{A}}\right)\end{array}$ & $\Delta \delta_{\mathrm{A}}$ & $\begin{array}{c}-\mathrm{P}(\mathrm{E}) \mathrm{Ph}_{2} \\
\left(\delta_{\mathrm{X}}\right)\end{array}$ & $\Delta \delta_{\mathrm{X}}$ \\
\hline $3 \mathbf{a}$ & $72.7 \mathrm{~d}(31.1)$ & 0.8 & $75.0 \mathrm{~d}$ & 31.1 \\
\hline $3 b$ & $72.4 \mathrm{~d}(28.4)$ & 0.5 & $77.2 \mathrm{~d}$ & 33.3 \\
\hline $3 c$ & $71.1 \mathrm{~d}(29.5)$ & -0.8 & $78.9 \mathrm{~d}$ & 35.0 \\
\hline $4 a$ & $72.7 \mathrm{~d}(28.3)$ & 3.9 & $79.3 \mathrm{~d}$ & 32.1 \\
\hline $4 b$ & $73.0 \mathrm{~d}(28.6)$ & 4.2 & $78.1 \mathrm{~d}$ & 30.9 \\
\hline $4 c$ & $71.1 \mathrm{~d}(28.7)$ & 2.3 & $80.0 \mathrm{~d}$ & 32.8 \\
\hline $5 a$ & $71.9 \mathrm{~d}(29.8)$ & 0.0 & $76.9 \mathrm{~d}$ & 33.0 \\
\hline $5 b$ & $71.3 \mathrm{~d}(28.4)$ & -0.6 & $75.2 \mathrm{~d}$ & 31.3 \\
\hline $5 c$ & $71.1 \mathrm{~d}(30.8)$ & -0.8 & $78.7 \mathrm{~d}$ & 34.8 \\
\hline $6 a$ & $71.9 \mathrm{~d}(28.3)$ & 3.1 & $79.1 \mathrm{~d}$ & 31.9 \\
\hline $6 b$ & $71.4 \mathrm{~d}(28.3)$ & 2.6 & $79.9 \mathrm{~d}$ & 32.7 \\
\hline $6 c$ & $72.1 \mathrm{~d}(29.9)$ & 3.3 & $77.9 \mathrm{~d}$ & 30.7 \\
\hline $7 \mathbf{a}$ & $92.4 \mathrm{~d}(91.8)$ & 21.9 & $76.0 \mathrm{~d}$ & 10.7 \\
\hline $7 b$ & $92.2 \mathrm{~d}(87.9)$ & 21.7 & $75.0 \mathrm{~d}$ & 9.7 \\
\hline $7 c$ & $94.2 \mathrm{~d}(100.4)$ & 23.7 & $79.5 \mathrm{~d}$ & 14.2 \\
\hline $7 d$ & $94.7 \mathrm{~d}(100.5)$ & 24.2 & $78.7 \mathrm{~d}$ & 13.4 \\
\hline $7 e$ & $94.7^{[\mathrm{b}]}$ & 24.2 & $78.4 \mathrm{~d}$ & 13.1 \\
\hline $7 f$ & $(-)^{[c]}$ & $(-)$ & $78.3 \mathrm{~d}$ & 13.0 \\
\hline $8 \mathbf{a}$ & $92.1 \mathrm{~d}(88.2)$ & 21.6 & $74.4 \mathrm{~d}$ & 9.1 \\
\hline $8 b$ & $91.7 \mathrm{~d}(83.7)$ & 21.2 & $73.6 \mathrm{~d}$ & 8.3 \\
\hline $8 \mathrm{c}$ & 95.7 d (99.2) & 25.2 & $78.8 \mathrm{~d}$ & 13.5 \\
\hline 8d & $93.7 \mathrm{~d}(101.2)$ & 23.2 & $79.3 \mathrm{~d}$ & 14.0 \\
\hline
\end{tabular}

[a] The ${ }^{31} \mathrm{P}\left\{{ }^{1} \mathrm{H}\right\}$ NMR spectra were recorded in $\mathrm{CDCl}_{3}$ at $298 \mathrm{~K}$ except for $\mathbf{3}$ and $\mathbf{8}$, in which cases a $1: 1$ mixture of $\mathrm{CDCl}_{3}$ and $\mathrm{CH}_{2} \mathrm{Cl}_{2}$ was used. The ${ }^{31} \mathrm{P}_{-}{ }^{31} \mathrm{P}$ coupling constants are given in parentheses $\left[\Delta \delta=\delta\right.$ (complex) $-\delta$ (free ligand)]. ${ }^{[\mathrm{b}]}$ Overlapped by signals arising from the $-\mathrm{PPh}\left(\mathrm{N}_{2} \mathrm{C}_{3} \mathrm{HMe}_{2}-3,5\right)$ phosphorus atom of isomer 7d. ${ }^{[c]}$ The signal could not be assigned unequivocally. 


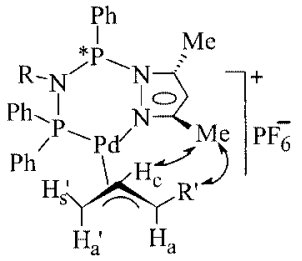

endo, syn, trans (3a, $4 \mathbf{a}, 5 \mathbf{a}$ or $6 \mathbf{a})$

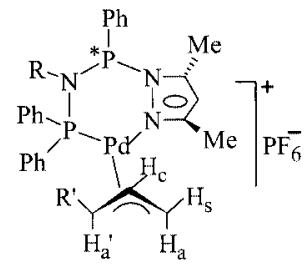

endo, syn, cis $(3 \mathrm{c}, 4 \mathrm{c}, 5 \mathrm{c}$ or $6 \mathrm{c})$

Figure 1. The three isomers of (allyl)(diphosphazane) $\mathrm{Pd}^{\mathrm{II}}$ complexes $\left[\mathrm{Pd}\left(\eta^{3}-\mathrm{R}^{\prime} \mathrm{C}_{3} \mathrm{H}_{4}\right)\left\{\eta^{2}-\mathrm{Ph}_{2} \mathrm{PN}(\mathrm{R}) \mathrm{PPh}\left(\mathrm{N}_{2} \mathrm{C}_{3} \mathrm{HMe}_{2}-3,5\right)\right\}\right]\left(\mathrm{PF}_{6}\right)$ $\left[\mathrm{R}^{\prime}=\mathrm{Me}\right.$ or $\mathrm{Ph}, \mathrm{R}=\mathrm{CHMe}_{2}$ or $\left.(S)-{ }^{*} \mathrm{CHMePh}\right]$ observed in solution; selective NOE contacts (shown by the arrows) revealed that, in the endo,syn,trans isomer, the central allyl proton and pyrazole3-Me protons were close to each other, whereas in the exo,syn,trans isomer, such an NOE contact with the central allyl proton was absent

Table 2. The ${ }^{13} \mathrm{C}$ NMR spectroscopic data for the allyl carbon nuclei of complexes $\mathbf{3}-\mathbf{8}$

\begin{tabular}{|c|c|c|c|}
\hline Complex $^{[\mathrm{a}]}$ & $\mathrm{C}_{\mathrm{t}}$ & $\mathrm{C}_{\mathrm{t}}^{\prime}$ & $\mathrm{C}_{\mathrm{c}}$ \\
\hline $3 \mathbf{a}$ & $105.0 \mathrm{~d}(29.8)^{[\mathrm{b}]}$ & $51.6 \mathrm{~d}(5.4)^{[\mathrm{c}]}$ & $117.2 \mathrm{~d}(6.2)$ \\
\hline $3 b$ & $94.8 \mathrm{~d}(28.9)^{[\mathrm{b}]}$ & 55.4 br. & $120.9 \mathrm{~d}(5.9)$ \\
\hline $4 a$ & $104.6 \mathrm{~d}(29.5)^{[\mathrm{b}]}$ & 52.1 br. & $117.4 \mathrm{~d}(5.5)$ \\
\hline $4 b$ & $94.6 \mathrm{~d}(28.6)^{[\mathrm{b}]}$ & 55.5 br. & $120.7 \mathrm{~d}(5.3)$ \\
\hline $4 c$ & $78.6 \mathrm{~d}(28.6)^{[\mathrm{b}]}$ & 72.5 br. & $117.4^{[\mathrm{d}]}$ \\
\hline $5 \mathbf{a}$ & $103.7 \mathrm{~d}(28.5)^{[\mathrm{b}]}$ & $54.8 \mathrm{~d}(3.8)^{[\mathrm{c}]}$ & $112.1 \mathrm{~d}(6.8)$ \\
\hline $5 b$ & $102.5 \mathrm{~d}(27.8)^{[\mathrm{b}]}$ & $54.7 \mathrm{~d}(3.9)^{[\mathrm{c}]}$ & $114.6 \mathrm{~d}(6.9)$ \\
\hline $5 c$ & $79.2 \mathrm{~d}(28.1)^{[\mathrm{b}]}$ & $76.8 \mathrm{~d}(4.2)^{[\mathrm{c}]}$ & $117.4 \mathrm{~d}(5.9)$ \\
\hline $6 a$ & $103.0 \mathrm{~d}(29.2)^{[\mathrm{b}]}$ & $53.9(3.9)^{[\mathrm{c}]}$ & $111.4 \mathrm{~d}(8.2)$ \\
\hline $6 \mathrm{~b}$ & $104.5 \mathrm{~d}(27.1)^{[\mathrm{b}]}$ & $55.5 \mathrm{~d}(4.6)^{[\mathrm{c}]}$ & $112.5 \mathrm{~d}(6.1)$ \\
\hline $6 c$ & $78.1 \mathrm{~d}(27.7)^{[\mathrm{b}]}$ & $64.3 \mathrm{~d}(5.4)^{[\mathrm{c}]}$ & $116.6 \mathrm{~d}(6.6)$ \\
\hline $7 \mathbf{a}$ & $96.0 \mathrm{~d}(30.7)^{[\mathrm{b}]}$ & $65.3 \mathrm{~s}$ & 119.4 br. s \\
\hline $7 b$ & $96.9 \mathrm{~d}(34.8)^{[\mathrm{b}]}$ & $65.3^{[\mathrm{e}]}$ & 120.2 br. s, \\
\hline $7 c$ & $68.6 \mathrm{~d}(34.9)^{[\mathrm{b}]}$ & 91.8 br. s & 119.8 br. s \\
\hline $7 d$ & $70.5 \mathrm{~d}(33.3)^{[\mathrm{b}]}$ & 89.4 br. s & $119.8^{[\mathrm{f}]}$ \\
\hline $8 a$ & $96.6 \mathrm{~d}(32.2)^{[\mathrm{b}]}$ & 66.5 br. s & 113.7 br. s \\
\hline $8 b$ & $97.9 \mathrm{~d}(30.7)^{[\mathrm{b}]}$ & 66.3 br. s & 114.2 br. s \\
\hline $8 c$ & $68.5 \mathrm{~d}(33.3)^{[\mathrm{b}]}$ & 94.0 br. s & 113.2 br. s \\
\hline 8d & 70.6 br. d $(24.1)^{[\mathrm{b}]}$ & 91.4 br. s & 113.9 br. s \\
\hline
\end{tabular}

[a] The ${ }^{13} \mathrm{C}$ NMR spectra were recorded in $\mathrm{CDCl}_{3}$ at $298 \mathrm{~K}$ except for 3 and $\mathbf{8}$, in which cases a 1:1 mixture of $\mathrm{CDCl}_{3}$ and $\mathrm{CH}_{2} \mathrm{Cl}_{2}$ was used. The ${ }^{13} \mathrm{C}-{ }^{31} \mathrm{P}$ coupling constants are given in parentheses. $\mathrm{C}_{\mathrm{t}}$ is the terminal allyl carbon atom trans to the coordinated phosphorus centre. $\mathrm{C}_{\mathrm{t}}{ }^{\prime}$ is the terminal allyl carbon atom cis to the coordinated phosphorus centre. $\mathrm{C}_{\mathrm{c}}$ is the central allyl carbon atom. ${ }^{[b]}{ }^{2} J_{\mathrm{P}, \mathrm{C} \text { trans. }}{ }^{[\mathrm{c}]}{ }^{2} J_{\mathrm{P}, \mathrm{C} \text { cis. }}{ }^{[\mathrm{d}]}$ Overlapped with central allyl carbon resonance of 4a. ${ }^{[e]}$ Overlapped with $\mathrm{C}_{t}{ }^{\prime}$ resonance of 7a. ${ }^{[\mathrm{f}]}$ Overlapped with central allyl carbon resonance of $7 \mathbf{c}$.

$51-56$ ppm, respectively) with ${ }^{2} J_{\mathrm{P}, \mathrm{C}}$ coupling constants in the $3-6 \mathrm{~Hz}$ range, typical for two-bond coupling of phosphorus and carbon nuclei in a cis orientation. It is well documented that in cationic allyl complexes with phosphorus ligands the ${ }^{31} \mathrm{P}$ nucleus shows a larger coupling constant with the terminal allyl carbon atom in the trans position than with that in the cis position. ${ }^{[11]}$ In all the major isomers (3a, $\mathbf{4 a}, \mathbf{5 a}$, and $\mathbf{6 a}$ ) and in the second most abundant isomers $(\mathbf{3 b}, \mathbf{4 b}, \mathbf{5 b}$, and $\mathbf{6 b})$, the coordinated phosphorus atom and the substituent on the allyl moiety had a trans disposition. The remaining isomers $(\mathbf{3 c}, \mathbf{4 c}, \mathbf{5 c}$, and 6c) were assigned structures in which the coordinated phosphorus atom and the substituent on the allyl moiety had a cis disposition. The $P, N$-coordination was also supported by the ${ }^{31} \mathrm{P}$ chemical shifts (see Table 1 ).

Transition metal complexes of the ligands $\mathbf{1 a}$ and $\mathbf{1 b}$ usually feature $P, P$-coordination. ${ }^{[9]}$ The driving force for $P, N$ coordination in the $\left(\eta^{3}\right.$-allyl)palladium complexes 3-6 might be the formation of a stable six-membered chelate ring around the palladium centre rather than the four-membered ring that would result from $P, P$-coordination. Moreover, coordination of a stronger $\sigma$-donor nitrogen atom would electronically stabilise the allyl-palladium bonding much more than coordination with a stronger $\pi$-acceptor phosphorus centre, by enhancing the metal-to-allyl backbonding. ${ }^{[12]}$ Such a pronounced electronic effect is well known ${ }^{[13]}$ and is reflected in the ${ }^{13} \mathrm{C}$ NMR parameters (see Table 2).

The ${ }^{1} \mathrm{H}$ NMR spectra of the complexes $3-\mathbf{6}$ showed three sets of four nonequivalent resonances for the allylic protons at $298 \mathrm{~K}$. The magnetic nonequivalence of the allylic protons arises because of the asymmetry in the ligands $\mathbf{1 a}$ and 1b. The presence of two anti-allyl protons in each set of signals indicated a syn arrangement of the allyl substituent with respect to the central allyl proton in each isomer. The major isomers of these complexes showed NOE contacts between the 3-Me protons of the pyrazole ring and the central allyl proton $\mathrm{H}_{\mathrm{c}}$. This result indicated that the central allyl hydrogen atom $\mathrm{H}_{\mathrm{c}}$ pointed towards the 3-Me group of the pyrazole. Hence, the major isomers $(\mathbf{3 a}-\mathbf{6 a})$ have the endo,syn,trans arrangement. ${ }^{[7 \mathrm{~b}, 14]}$ For the second set of isomers $(\mathbf{3 b}-\mathbf{6 b})$, the pyrazole $3-\mathrm{Me}$ protons did not show NOE contacts to the central allyl proton $\mathrm{H}_{\mathrm{c}}$ but there was an NOE contact to the anti-allyl proton $\mathrm{H}_{\mathrm{a}}$. The central allyl proton $\mathrm{H}_{\mathrm{c}}$ thus pointed away from the 3-Me group of the pyrazole, and so these isomers $(\mathbf{3 b}-\mathbf{6 b})$ could be assigned the exo,syn,trans configuration. The central allyl proton resonances for the endo isomers $\mathbf{3 a}-\mathbf{6 a}$ appeared at a more deshielded region $(\delta \approx 5.7 \mathrm{ppm})$ than those $(\delta \approx$ $4.5 \mathrm{ppm}$ ) for the exo isomers $\mathbf{3 b}-\mathbf{6 b}$. This trend has also been observed for other allylpalladium complexes $\left[\mathrm{Pd}\left(\eta^{3}-\right.\right.$ $\left.\left.1,3-\mathrm{R}_{2}^{\prime} \mathrm{C}_{3} \mathrm{H}_{3}\right)\left\{\eta^{2}-\mathrm{Ph}_{2} \mathrm{PN}(\mathrm{R}) \mathrm{PPh}\left(\mathrm{N}_{2} \mathrm{C}_{3} \mathrm{HMe}_{2}-3,5\right)\right\}\right]\left(\mathrm{PF}_{6}\right)$ $\left[\mathrm{R}^{\prime}=\mathrm{H}, \mathrm{Me}\right.$ or $\mathrm{Ph} ; \mathrm{R}=\mathrm{CHMe}_{2}$ or $\left.(S)-* \mathrm{CHMePh}\right]$ bearing $\mathbf{1 a}$ and $\mathbf{1 b}$ ligands. ${ }^{[15]}$ On this basis, we assigned the endo,syn,cis configuration (see Figure 1) to the third set of minor isomers $(\mathbf{4 c}-\mathbf{6 c})$ as the chemical shifts of the $\mathrm{H}_{\mathrm{c}}$ protons in each of these isomers were close to those observed for $4 \mathbf{a}-\mathbf{6 a}$. The cis geometries and the $s y n$-allylic arrangements for the minor isomers were confirmed by ${ }^{13} \mathrm{C} N \mathrm{NM}$ (see Table 2) and 2-D NMR spectroscopy, respectively. The ${ }^{13} \mathrm{C}$ and ${ }^{1} \mathrm{H}$ NMR signals for isomer $3 \mathrm{c}$ could not be ob- 
served because of its low abundance and poor solubility in $\mathrm{CDCl}_{3}$. However, the ${ }^{31} \mathrm{P}$ chemical shift and P-P coupling constant values for $\mathbf{3 c}$ were similar to those of $\mathbf{4 c}$, and so an endo,syn,cis configuration may tentatively be assigned to 3c. An important difference was observed between the relative abundances of the isomers of 1-methylallyl and 1phenylallyl derivatives. For the 1-methylallyl derivatives (3 and 4), the exo,syn,trans isomers were present to an extent of $40 \%$, whereas for the 1-phenylallyl derivatives ( 5 and $\mathbf{6}$ ), the exo,syn,trans isomers were present to an extent of less than $10 \%$. The low relative abundances of the exo,syn,trans isomers in the case of 1-phenylallyl derivatives is probably related to the steric demand of the larger phenyl group on the allyl moiety.

\section{Dynamic Behaviour of the Complexes 3-6}

The dynamic behaviour of the complexes 3-6 was examined by ${ }^{1} \mathrm{H}-{ }^{1} \mathrm{H}$ NOESY and ROESY spectra. No exchange among the isomers of complexes 4-6 was observed in $\mathrm{CDCl}_{3}$ at $298 \mathrm{~K}$. For complex 3, on the other hand, exchange between the isomers $\mathbf{3} \mathbf{a}$ and $\mathbf{3 b}$ was observed at $298 \mathrm{~K}$ in $\left[\mathrm{D}_{6}\right]$ acetone. The high-temperature $(323 \mathrm{~K}){ }^{1} \mathrm{H}-{ }^{1} \mathrm{H}$ NOESY and ROESY spectra for the complexes $\mathbf{4}$ and $\mathbf{5}$ revealed that the major isomers $\mathbf{4 a}$ and $\mathbf{5 a}$ exchanged with the minor isomers $\mathbf{4 b}$ and $\mathbf{5 b}$, respectively, in a way similar to that observed for the isomers $\mathbf{3 a}$ and $\mathbf{3 b}$ at $298 \mathrm{~K}$. The phase-sensitive ${ }^{1} \mathrm{H}-{ }^{1} \mathrm{H}$ NOESY spectrum of complex 4 recorded at $323 \mathrm{~K}$ is shown in Figure 2 and the exchange re-

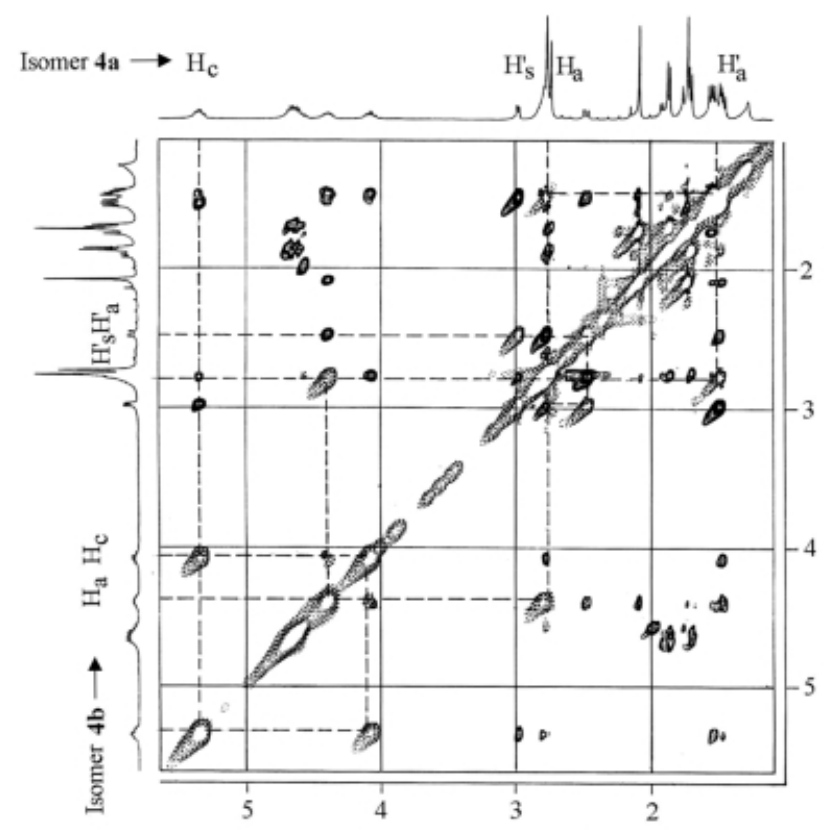

Figure 2. The ${ }^{1} \mathrm{H}_{-}{ }^{1} \mathrm{H}$ phase-sensitive NOESY spectrum $\left(\mathrm{CDCl}_{3}\right.$, $400 \mathrm{MHz}$ ) of complex 4 at $323 \mathrm{~K}$, showing the exchange crosspeaks in the isomers $\mathbf{4 a}$ and $\mathbf{4 b}$

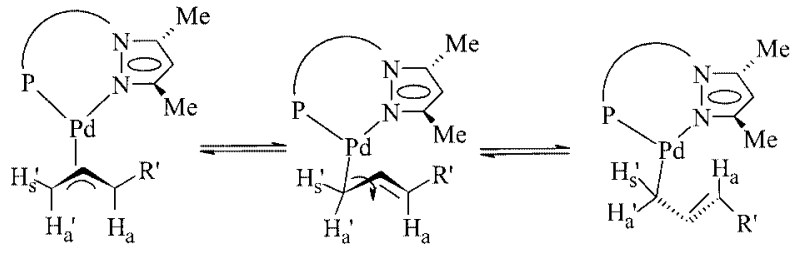

endo, syn, trans
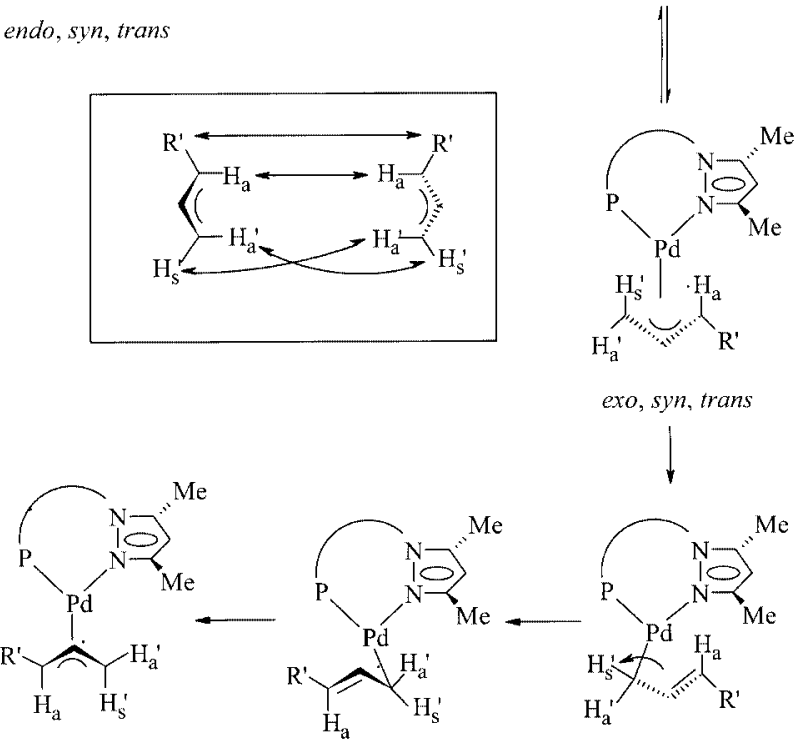

endo, syn, cis

Scheme 2

sults are summarised in Scheme 2. Pregosin and coworkers ${ }^{[16]}$ have shown that this type of exchange can be explained in terms of a selective opening of the $\eta^{3}$-allyl moiety at the trans position with respect to the phosphorus centre to generate an $\eta^{1}$-bonded intermediate, followed by a rotation around the $\mathrm{sp}^{3}-\mathrm{sp}^{2} \mathrm{C}-\mathrm{C}$ bond and reversion to the $\eta^{3}$-mode of coordination by the other face of the allyl group. This type of electronic control over the interconversion process is especially well known in cases of mixeddonor P,N-, P,S-, and P,O- bidentate ligand systems. ${ }^{[17-19]}$ The minor isomers $(\mathbf{4 c}$ and $\mathbf{5 c}$ ) did not show any observable exchange even at $323 \mathrm{~K}$, but their formation can be interpreted, starting from isomers $\mathbf{4 b}$ and $\mathbf{5 b}$, respectively, in terms of cis,trans isomerisation by rotation around the $\mathrm{Pd}-\mathrm{C}$ bond in the corresponding $\eta^{1}$-bonded intermediate.

\section{Solid-State Structure of Complex 5a}

The details of the crystal data are presented in Table 3. The molecular structure is shown in Figure 3. The solidstate structure reveals the presence of only one isomer with $P, N$-coordination and a trans disposition of the syn-allylphenyl group with respect to the coordinated phosphorus centre. The central allyl carbon atom C(2) and the 3-methyl carbon atom $\mathrm{C}(10)$ of the pyrazole ring in $\mathbf{5 a}$ lie on the same side of the coordination plane defined by $\mathrm{P}(2)-\mathrm{Pd}(1)-\mathrm{N}(3)$, thus revealing an endo arrangement in the solid state (endo refers to the relative orientation of the central $\mathrm{C}-\mathrm{H}$ vector pointing towards the 3-methyl group on the pyrazole ring $\left.{ }^{[7 b, 14]}\right)$. The bonding parameters fall in the expected ranges observed for cationic allylpalladium 


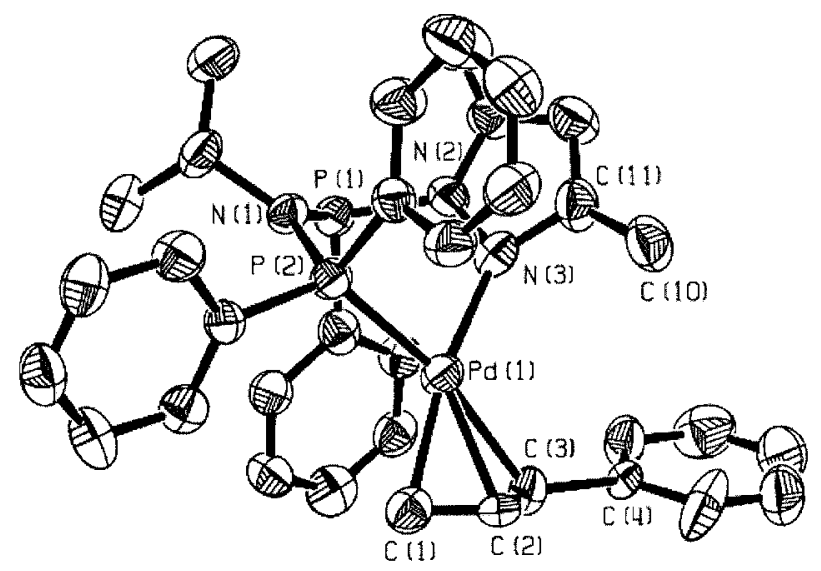

Figure 3. Molecular structure of $\mathbf{5 a}$ in the solid state (the hydrogen atoms and the hexafluorophosphate anion are not shown); selected bond lengths $[\mathrm{A}]$ and angles $\left[{ }^{\circ}\right]: \operatorname{Pd}(1)-\mathrm{C}(1)=2.075(2)$, $\mathrm{Pd}(1)-\mathrm{C}(2)=2.137(2), \mathrm{Pd}(1)-\mathrm{C}(3)=2.263(2), \mathrm{Pd}(1)-\mathrm{P}(2)=$ 2.293(3), $\mathrm{Pd}(1)-\mathrm{N}(3)=2.075(1) ; \mathrm{N}(3)-\mathrm{Pd}(1)-\mathrm{P}(2)=85.4(3)$, $\mathrm{C}(1)-\mathrm{Pd}(1)-\mathrm{C}(3)=64.0(8), \mathrm{N}(3)-\mathrm{Pd}(1)-\mathrm{C}(1)=169.8(5)$, $\mathrm{C}(3)-\mathrm{Pd}(1)-\mathrm{P}(2)=167.8(6), \mathrm{P}(2)-\mathrm{N}(1)-\mathrm{P}(1)=122.5(6)$

complexes bearing P,N-ligands. ${ }^{[17 b, 20]}$ The coordination geometry around the metal centre is distorted squareplanar, with the $\mathrm{N}(3)-\mathrm{Pd}(1)-\mathrm{P}(2)$ and $\mathrm{C}(1)-\mathrm{Pd}(1)-\mathrm{C}(3)$ bond angles $85.4(3)^{\circ}$ and $64.0(8)^{\circ}$, respectively. The two terminal allyl carbon atoms are not exactly coplanar with the coordination plane formed by $\mathrm{P}(2)-\mathrm{Pd}(1)-\mathrm{N}(3)$. The distances of the terminal allyl carbon atoms $\mathrm{C}(1)$ and $\mathrm{C}(3)$ are $0.120 \AA$ and $0.089 \AA$, respectively, whereas the central allyl carbon atom $\mathrm{C}(2)$ lies at a distance of $0.703 \AA$ from the plane. The terminal $\mathrm{Pd}-\mathrm{C}(\mathrm{allyl})$ bond lengths are significantly different from one another. The carbon atom trans to the phosphorus atom displays the expected longer bond length $[\operatorname{Pd}(1)-C(3)=2.263(2) \AA]$, as compared to its partner trans to the nitrogen atom $[\mathrm{Pd}(1)-\mathrm{C}(1)=2.075(2) \AA]$. This is consonant with the larger trans influence of the phosphorus donor. ${ }^{[13]}$ This elongation of the $\mathrm{Pd}-\mathrm{C}$ (terminal allyl) bond length trans to the phosphorus atom relative to that trans to the nitrogen atom is consistent with the proposed mechanism (Scheme 2) involving selective opening of one of the allyl termini. The six-membered chelate ring adopts a distorted boat conformation; $\mathrm{P}(2)$ is almost coplanar (deviation $0.168 \AA$ ) with the plane formed by $\mathrm{N}(1)-\mathrm{N}(2)-\mathrm{N}(3)$, while $\mathrm{Pd}(1)$ and $\mathrm{P}(1)$ lie on the same side of this plane at 1.063 and $0.778 \AA$, respectively. The $\mathrm{P}(1)-\mathrm{N}(1)-\mathrm{P}(2)$ bond angle is increased to $122.5(6)^{\circ}$, compared to a value of ca. $100^{\circ}$ observed for $P, P$-coordinated complexes. ${ }^{[9]}$

\section{NMR Studies on Complexes 7 and 8}

The ${ }^{31} \mathrm{P}\left\{{ }^{1} \mathrm{H}\right\}$ NMR spectrum of an analytically pure sample of $\left[\mathrm{Pd}\left(\eta^{3}-1-\mathrm{MeC}_{3} \mathrm{H}_{4}\right)\left\{\eta^{2}-\mathrm{Ph}_{2} \mathrm{P}(\mathrm{S}) \mathrm{N}\left(\mathrm{CHMe}_{2}\right) \mathrm{PPh}-\right.\right.$ $\left.\left.\left(\mathrm{N}_{2} \mathrm{C}_{3} \mathrm{HMe}_{2}-3,5\right)\right\}\right]\left(\mathrm{PF}_{6}\right)(7)$ in $\mathrm{CDCl}_{3}$ showed ten doublets arising from six AX spin systems. The two missing doublets (from the fifth and sixth isomers) overlapped with those arising from the major isomers, as revealed by a ${ }^{31} \mathrm{P}-{ }^{31} \mathrm{P}$ COSY spectrum. A 24-line spectrum was consistent with the formation of six isomers. The relative integrated intens- ities of the doublets indicated that the six isomers were present in the ratio 21:10:9:6:2:1. The allyl ${ }^{13} \mathrm{C}$ resonances for these isomers were assigned by recourse to a ${ }^{13} \mathrm{C}-{ }^{1} \mathrm{H}$ HSQC experiment. Analysis of the ${ }^{13} \mathrm{C}$ NMR spectrum showed a doublet pattern with a ${ }^{2} J_{\mathrm{P}, \mathrm{C}}$ value of ca. $30 \mathrm{~Hz}$ for one of the two terminal allyl carbon resonances in the cases of isomers $7 \mathbf{a}-\mathbf{7 d}$, indicating bonding of one phosphorus atom with the palladium centre. From the ${ }^{31} \mathrm{P}$ chemical shifts (Table 1 and see also below), we were able to conclude that the pyrazolyl-bearing phosphorus atom and the sulfur atom were coordinated to the palladium centre. This conclusion was supported by the ${ }^{13} \mathrm{C}$ chemical shifts of the allyl carbon nuclei, when compared with the chemical shifts of allyl carbon nuclei of $P, N$-coordinated complexes 3-6 (see Table 2). It may be noted that the chemical shifts of allyl carbon nuclei trans to the nitrogen atom indicated that they were more shielded (by about $10-20 \mathrm{ppm}$ ) than the allyl carbon nuclei trans to the sulfur atom, if we consider the similar allyl isomers in both cases. Ligand $\mathbf{1 c}$, in contrast to $\mathbf{1 a}$ and $\mathbf{1 b}$, thus did not coordinate through the nitrogen atom of the pyrazole ring, $P, S$-coordination presumably being favoured because of the formation of a stable five-membered ring around the palladium centre. The competitive $N, S$-coordination would give rise to the formation of a seven-membered chelate ring around the palladium atom. The fifth and sixth isomers (7e and 7f) could not be detected by ${ }^{13} \mathrm{C}$ NMR, owing to their low relative concentrations (present at less than 5\%). However, the similarity of their ${ }^{31} \mathrm{P}$ chemical shifts with those of other isomers $(7 \mathbf{a}-7 \mathbf{d})$ and the multiplicities of the allyl resonances in the ${ }^{1} \mathrm{H}$ NMR spectrum suggested that these isomers must be structurally closely related to $\mathbf{7 a}-\mathbf{7 d}$.

The ${ }^{1} \mathrm{H}$ NMR spectrum of complex 7 showed several broad signals; in addition, the chemical shifts of several allylic proton resonances were very close. However, a careful analysis of various 2-D NMR spectra $\left({ }^{1} \mathrm{H}-{ }^{1} \mathrm{H}\right.$ DQF COSY, NOESY, and ROESY) resulted in a correct assignment of the allyl protons. The intra-allyl NOESY spectrum revealed that in the four isomers $\mathbf{7 a - 7 d}$ there was a syn arrangement of the allylmethyl group with respect to the central allyl proton $\left(\mathrm{H}_{\mathrm{c}}\right)$, while in the isomers $7 \mathbf{e}$ and $7 \mathbf{f}$ there was an anti arrangement of the allylmethyl group and the central allyl proton. The interligand NOE cross-peaks confirmed the configurations of these isomers. One of the methyl groups of the pyrazole ring came close to the central allyl proton $\mathrm{H}_{\mathrm{c}}$ and to the syn-proton $\mathrm{H}_{\mathrm{s}}{ }^{\prime}$ in the endo isomer, whereas for the exo isomer the anti-allyl proton $\mathrm{H}_{\mathrm{a}}{ }^{\prime}$ showed NOE contact with this methyl group. The structures assigned to the six isomers on the basis of NMR measurements are shown in Figure 4. The structural assignments for $7 \mathbf{a}$ and $\mathbf{7 b}$ are unequivocal, while there is some uncertainty with regard to the structural assignments for the other isomers $(\mathbf{7} \mathbf{c}-\mathbf{7 f})$ because of the overlap of the pyrazole methyl proton signals arising from these minor isomers. However, studies on the exchange behaviour of the isomers (see below) lent support to the assignments.

The ${ }^{1} \mathrm{H}-{ }^{1} \mathrm{H}$ phase-sensitive NOESY and ROESY spectra at $298 \mathrm{~K}$ in $\mathrm{CDCl}_{3}$ showed that isomers $7 \mathbf{a}-\mathbf{7 d}$ were in 


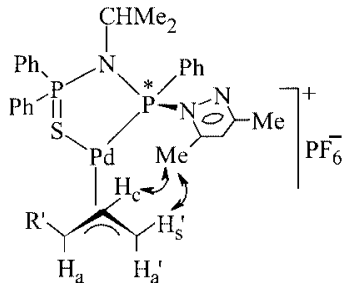

endo, syn, trans $(\mathbf{7 a}, \mathbf{8} \mathbf{a})$

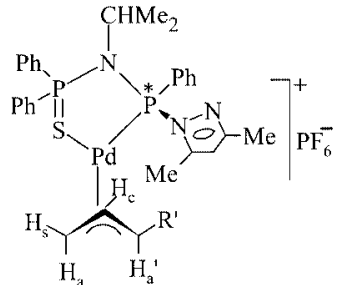

endo, syn, cis $(7 \mathbf{e}, 8 \mathbf{c})$

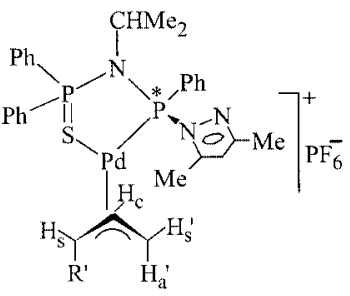

endo, anti, trans (7e)

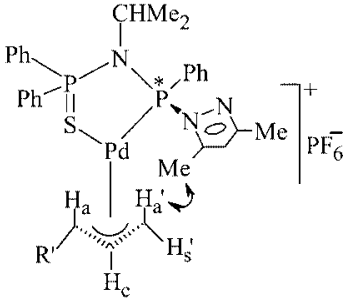

exo, syn, trans $(\mathbf{7 b}, \mathbf{8 b})$

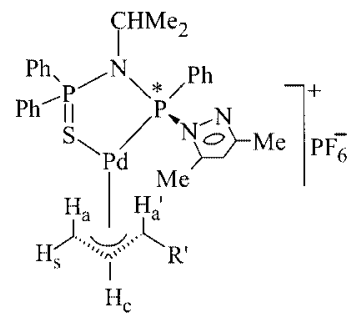

exo, syn, cis $(\mathbf{7 d}, \mathbf{8 d})$

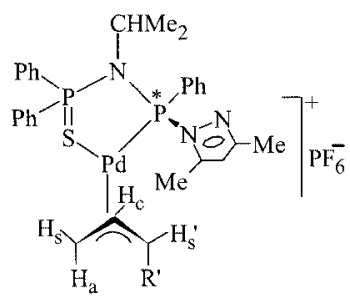

endo, anti, cis (7f)

Figure 4. The six isomers for the (methylallyl)palladium complex $\left[\mathrm{Pd}\left(\eta^{3}-\mathrm{MeC}_{3} \mathrm{H}_{4}\right)\left\{\eta^{2}-\mathrm{Ph}_{2} \mathrm{P}(\mathrm{S}) \mathrm{N}\left(\mathrm{CHMe}_{2}\right) \mathrm{PPh}\left(\mathrm{N}_{2} \mathrm{C}_{3} \mathrm{HMe}_{2}-3,5\right)\right\}\right]-$ $\left(\mathrm{PF}_{6}\right)(7)$ and the four isomers observed in solution for the (phenylallyl)palladium complex $\left[\mathrm{Pd}\left(\eta^{3}-\mathrm{PhC}_{3} \mathrm{H}_{4}\right)\left\{\eta^{2}-\mathrm{Ph}_{2} \mathrm{P}(\mathrm{S}) \mathrm{N}\left(\mathrm{CHMe}_{2}\right)-\right.\right.$ $\left.\left.\mathrm{PPh}\left(\mathrm{N}_{2} \mathrm{C}_{3} \mathrm{HMe}_{2}-3,5\right)\right\}\right]\left(\mathrm{PF}_{6}\right)(\mathbf{8})$

equilibrium with one another. The exchange followed an $\eta^{3}-\eta^{1}-\eta^{3}$ pathway, with the opening of the allyl terminus at the position trans with respect to the phosphorus centre. The isomer 7a showed dynamic behaviour with isomer $\mathbf{7 b}$ through a syn,anti isomerisation process. Hence, $7 \mathbf{b}$ could be assigned the exo,syn,trans structure, as the starting isomer 7a had the endo,syn,trans structure. On the other hand, the isomer $7 \mathbf{a}$ transformed into $\mathbf{7 d}$ by a cis,trans isomerisation process, indicating that $\mathbf{7 d}$ should be the exo,syn,cis isomer. The isomer $\mathbf{7 b}$ showed cis,trans exchange with the isomer 7c, and so the isomer 7c should be endo,syn,cis. Exchange cross-peaks were also observed between isomers 7a and $\mathbf{7 c}$, as well as between isomers $\mathbf{7 b}$ and $\mathbf{7 d}$. The exchange equilibria may be represented schematically as in Scheme 3.

The ${ }^{31} \mathrm{P}\left\{{ }^{1} \mathrm{H}\right\}$ NMR spectrum of complex 8 (see Figure 5) revealed eight doublets arising from four isomers. A de-

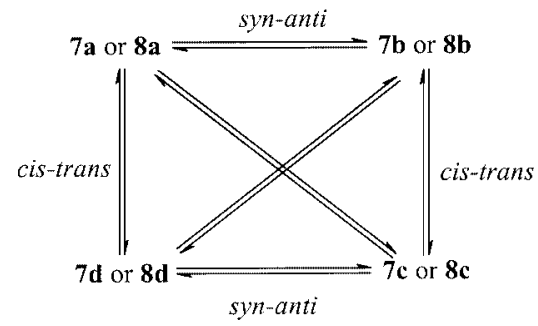

Scheme 3

tailed NMR investigation $\left({ }^{1} \mathrm{H}\right.$ NMR, ${ }^{13} \mathrm{C}$ NMR, ${ }^{1} \mathrm{H}-{ }^{1} \mathrm{H}$ DQF COSY, NOESY, and ROESY) indicated that all four isomers involved $P, S$-coordination with syn-allylphenyl arrangement, and that the major isomer had the endo,syn,trans configuration (8a) as shown in Figure 4. In contrast to complex 7, no anti isomer was formed in this case, owing to the presence of a relatively more bulky phenyl group on the allyl moiety. The exchange behaviour for $\mathbf{8 a - 8 d}$ was similar to that observed for $\mathbf{7 a - 7 d}$; the exchanges are depicted in Scheme 4. The results can be explained in terms of the pathways shown in Scheme 5, the isomers $\mathbf{8 a}$ and $\mathbf{8 d}$ being related by cis,trans isomerisation and $\mathbf{8 a}$ and $\mathbf{8 b}$ by syn,anti isomerisation, with both processes occurring by means of a selective opening of the terminal allyl $\mathrm{Pd}-\mathrm{C}$ bond located trans to the better $\pi$-acceptor phosphorus centre. Hence, the conversion of $\mathbf{8 a}$ into $\mathbf{8 b}$ or $\mathbf{8 d}$ was electronically controlled.

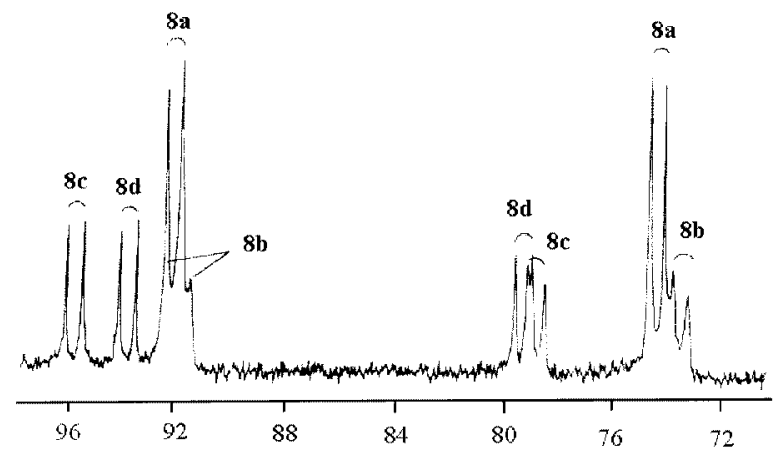

Figure 5. The ${ }^{31} \mathrm{P}\left\{{ }^{1} \mathrm{H}\right\}$ NMR spectrum $\left(\mathrm{CDCl}_{3}, 161.9 \mathrm{MHz}\right)$ of complex 8 at $298 \mathrm{~K}$, showing the presence of four isomers
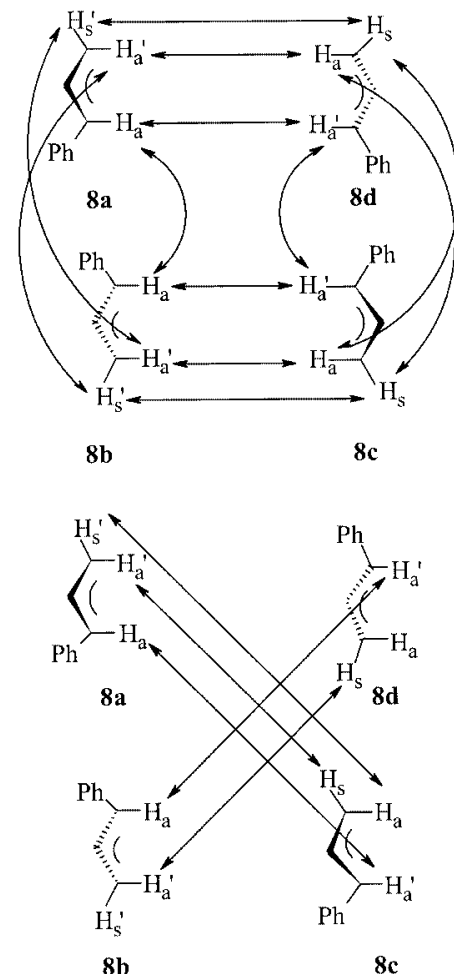

Scheme 4 


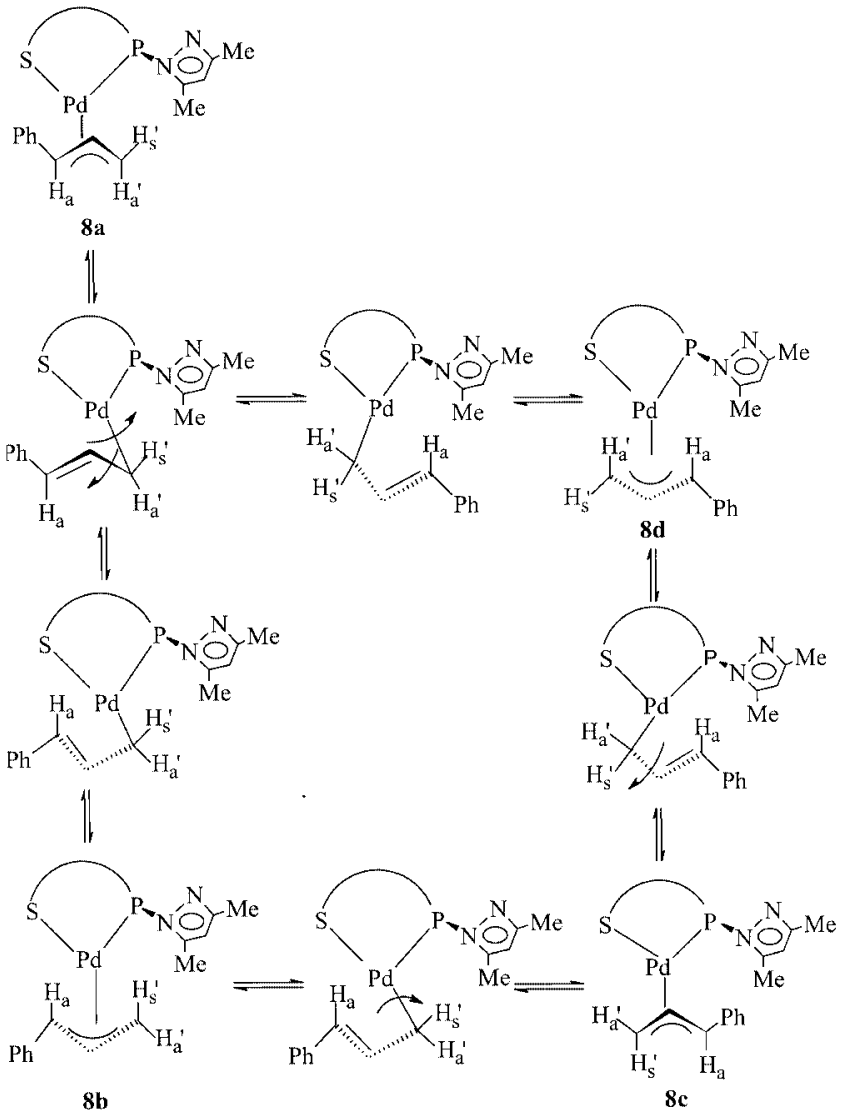

Scheme 5

In contrast, the isomerisation between $\mathbf{8 d}$ and $\mathbf{8 c}$ took place by a selective opening of the $\eta^{3}$-allyl group at the cis position with respect to the phosphorus centre, and hence was subject to steric control over the opening of the $\eta^{3}$-allyl moiety. The presence of a bulky allylphenyl group at the position cis to the $-\mathrm{PPh}\left(\mathrm{N}_{2} \mathrm{C}_{3} \mathrm{HMe}_{2}-3,5\right)$ group in isomer 8d exerted a more pronounced steric repulsion than in isomer 8a, in which the allylphenyl group resided at the position cis to the sterically less demanding $-\mathrm{P}(\mathrm{S}) \mathrm{Ph}_{2}$ group. Hence, the opening of the $\eta^{3}$-allyl moiety to a three-coordinated $\eta^{1}$-bonded intermediate in isomer $\mathbf{8 d}$ relieved the steric strain. This type of steric control over syn,anti isomerisation has been observed in the case of a cationic allylpalladium complex bearing a P,S-ligand with a bulky allyl moiety. ${ }^{[18]}$ Moreover, the isomer 8a exchanged with $\mathbf{8 c}$, and $\mathbf{8 b}$ exchanged with $\mathbf{8 d}$. Direct exchange between isomers 8a and $\mathbf{8 c}$ or between $\mathbf{8 b}$ and $\mathbf{8 d}$ should not be permitted, in view of their structural differences. However, NMR measurements clearly indicated exchange between $\mathbf{8 a}$ and $\mathbf{8 c}$ as well as $\mathbf{8 b}$ and $\mathbf{8 d}$. The exchange information was transmitted via the intermediates $\mathbf{8 b}$ or $\mathbf{8 d}$, resulting in an equilibrium among all four isomers $\mathbf{8 a}-\mathbf{8 d}$. The rapid dynamic processes for $\mathbf{7}$ and $\mathbf{8}$ were most probably related to the fact that the free nitrogen atom on the pyrazole ring can coordinatively interact with the palladium centre in the $\eta^{1}$ bonded intermediate. Such an interaction would stabilize the $\eta^{1}$-bonded intermediate and could accelerate the dynamic process. It is well known that catalytic amounts of anions such as chloride or fluoride or polar solvents such as DMSO and acetonitrile, which can coordinate to the palladium centre, accelerate the dynamic processes in allylpalladium complexes. ${ }^{[21]}$

\section{Trends in ${ }^{31} \mathbf{P}$ Chemical Shifts}

The ${ }^{31} \mathrm{P}$ resonances were assigned on the basis of the $\Delta \delta$ $[\Delta \delta=\delta$ (complex $)-\delta$ (free ligand $)]$ and sensitivity of the chemical shifts upon variation of the allyl moiety (see Table 1). The chemical shifts of one of the phosphorus nuclei in each of complexes 3-6 lay in the $\delta=71-73 \mathrm{ppm}$ range, with $\Delta \delta$ being only $4.2-0.5 \mathrm{ppm}$. The constancy in the magnitude of chemical shifts on changing the allyl component and the low $\Delta \delta$ value suggested that this chemical shift could be assigned to the noncoordinated phosphorus atom bearing the pyrazole moiety. On the other hand, the chemical shifts of the other phosphorus nuclei showed a greater range of variation $(\delta=75-80 \mathrm{ppm})$. These phosphorus chemical shifts lay very much further downfield from that of the free ligand, and the magnitude of $\Delta \delta$ was in the 30.7-35.0 ppm range. Hence, this chemical shift was assigned to the coordinated $-\mathrm{PPh}_{2}$ phosphorus atom. For the $P, S$-coordinated complexes 7 and $\mathbf{8}$, the $-\mathrm{P}(\mathrm{S}) \mathrm{Ph}_{2}$ and the $-\mathrm{PPh}$ (pyrazole) chemical shifts were assigned the values $\delta=73.6-79.5$ and $91.7-95.7 \mathrm{ppm}$, respectively, based on the magnitude of $\Delta \delta$ and chemical shifts observed for allylpalladium complexes of the ligands $\mathrm{Ph}_{2} \mathrm{P}(\mathrm{S}) \mathrm{N}\left(\mathrm{CHMe}_{2}\right) \mathrm{PPh}_{2}$ and $\mathrm{Ph}_{2} \mathrm{P}(\mathrm{S}) \mathrm{N}\left(\mathrm{CHMe}_{2}\right) \mathrm{P}(\mathrm{S})-$ $\mathrm{Ph}_{2}$, and also the chemical shifts of $P, P$-coordinated complexes of 1a. ${ }^{[15]}$

With regard to $\mathrm{P}-\mathrm{P}$ couplings, two observations were worthy of note:

(1) The ${ }^{2} J_{\mathrm{P}, \mathrm{P}}$ values for $P, N$-coordinated complexes of $\mathbf{1 a}$ and $1 \mathbf{b}$ lay in the $29-31 \mathrm{~Hz}$ range, whereas ${ }^{2} J_{P, P}$ values for $P, P$-coordinated allyl complexes are observed in the range of ca. $100 \mathrm{~Hz} .^{[15]}$

(2) The ${ }^{2} J_{\mathrm{P}, \mathrm{P}}$ values for the $P, S$-coordinated complexes of 1c were in the $80-100 \mathrm{~Hz}$ range.

\section{Conclusions}

Diphosphazane ligands of the type $\mathrm{Ph}_{2} \mathrm{P}(\mathrm{E}) \mathrm{N}(\mathrm{R})$ $\mathrm{PPh}\left(\mathrm{N}_{2} \mathrm{C}_{3} \mathrm{HMe}_{2}-3,5\right)(\mathbf{1})$, bearing a stereogenic phosphorus centre, exhibited diverse allylpalladium chemistry including various fluxional processes in solution. The preferred mode of coordination with the ligands $\mathrm{Ph}_{2} \mathrm{PN}(\mathrm{R}) \mathrm{PPh}$ $\left(\mathrm{N}_{2} \mathrm{C}_{3} \mathrm{HMe}_{2}-3,5\right)\left[\mathrm{R}=\mathrm{CHMe}_{2}(\mathbf{1 a})\right.$ or $\left.(S)-{ }^{*} \mathrm{CHMePh}(\mathbf{1 b})\right]$ was through the phosphorus and nitrogen atoms rather than the usually observed $P, P$-coordination. The former mode of coordination should electronically stabilise the allyl-palladium bonding, besides giving rise to the formation of a six-membered chelate ring. On the other hand, the monosulfide ligand $\mathrm{Ph}_{2} \mathrm{P}(\mathrm{S}) \mathrm{N}(\mathrm{R}) \mathrm{PPh}\left(\mathrm{N}_{2} \mathrm{C}_{3} \mathrm{HMe}_{2}-3,5\right)$ (1c) displayed $P, S$-coordination and also gave rise to a larger number of diastereomers with different allylic arrangements than observed in the $P, N$-coordinated ligands (1a and 1b), which were more selective towards stabilisation of particu- 
lar allyl diastereomers. In addition, in the case of $P, N$-coordinated complexes, there was a drastic decrease in the relative abundances of the exo,syn,trans isomers of 1-phenylallyl derivatives (below $10 \%$ ) compared to those $(40 \%)$ of the exo,syn,trans isomers of 1-methylallyl derivatives. Such a trend was not observed for the $P, S$-coordinated complexes. As far as the dynamic behaviour is concerned, the activation barriers for exchange processes among various allyl isomers bearing the $\mathrm{P}, \mathrm{S}$-ligand were less than those observed for the allyl isomers formed by P,N-ligands. The exchange pathway involved an $\eta^{1}$-allyl species generated by the opening of the $\eta^{3}$-allyl moiety at the position trans with respect to phosphorus atom in the case of $P, N$-coordinated complexes, and so was subject to electronic control. In the case of $P, S$-coordinated complexes, on the other hand, exchange among the allyl diastereomers occurred through the opening of the $\eta^{3}$-allyl moiety at either end (both trans with respect to the phosphorus atom as well as the sulfur atom). One possible reason for this difference is that the trans influences exerted by the two donor atoms - namely, phosphorus and sulfur - of the P,S-ligand (1c) would be reasonably similar to each other, whereas the trans influence of the phosphorus atom of the $\mathrm{P}, \mathrm{N}$-ligand $(\mathbf{1} \mathbf{a}$ or $\mathbf{1 b})$ would be much larger than that of the nitrogen atom, as evident from the ${ }^{13} \mathrm{C}$ chemical shift values of the allyl termini.

\section{Experimental Section}

General Remarks: Reactions and manipulations were carried out under purified nitrogen by standard Schlenk and vacuum-line techniques. The solvents were purified by standard procedures ${ }^{[22]}$ and distilled under nitrogen. The chloro-bridged allyl dimers $\left[\mathrm{Pd}\left(\eta^{3}-1-\right.\right.$ $\left.\left.\mathrm{MeC}_{3} \mathrm{H}_{4}\right)(\mu-\mathrm{Cl})\right]_{2}$ and $\left[\mathrm{Pd}\left(\eta^{3}-1-\mathrm{PhC}_{3} \mathrm{H}_{4}\right)(\mu-\mathrm{Cl})\right]_{2}$ were prepared as previously described. ${ }^{[23]}$ Diphosphazane ligands 1a, the $\left(S_{\mathrm{C}} R_{\mathrm{P}}\right)$ diastereomer of $\mathbf{1 b}$ and diphosphazane monosulfide $\mathbf{1} \mathbf{c}$ were prepared according to literature procedures. ${ }^{[8 \mathrm{~d}, 9 \mathrm{c}]}$ The NMR spectra were recorded with Bruker DRX $500 \mathrm{MHz}$ and Bruker AMX $400 \mathrm{MHz}$ spectrometers. Chemical shifts downfield from the reference standard were assigned positive values. Elemental analyses were carried out with a Perkin-Elmer $2400 \mathrm{CHN}$ analyser. The ${ }^{31} \mathrm{P}\left\{{ }^{1} \mathrm{H}\right\}$ and ${ }^{13} \mathrm{C}$ NMR spectroscopic data are given in Tables 1 and 2, respectively. The remaining NMR spectroscopic data are given below.

\section{Synthesis of Palladium Complexes}

$\left[\mathrm{Pd}\left(\eta^{3}-1-\mathrm{MeC}_{3} \mathrm{H}_{4}\right)\left\{\eta^{2}-\mathrm{Ph}_{2} \mathrm{PN}\left(\mathrm{CHMe}_{2}\right) \mathrm{PPh}\left(\mathrm{N}_{2} \mathrm{C}_{3} \mathrm{HMe}_{2}-3,5\right)\right\}\right]-$ (PF $\mathbf{P F}_{\mathbf{6}}$ (3): A mixture of $\left[\mathrm{Pd}\left(\eta^{3}-1-\mathrm{MeC}_{3} \mathrm{H}_{4}\right)(\mu-\mathrm{Cl})\right]_{2} \quad(0.039 \mathrm{~g}$, $\left.0.99 \cdot 10^{-4} \mathrm{~mol}\right), \mathrm{NH}_{4} \mathrm{PF}_{6}\left(0.033 \mathrm{~g}, 2.02 \cdot 10^{-4} \mathrm{~mol}\right)$, and $1 \mathrm{a}(0.095 \mathrm{~g}$, $2.13 \cdot 10^{-4} \mathrm{~mol}$ ) was dissolved in $20 \mathrm{~mL}$ of acetone. The solution was stirred for $2 \mathrm{~h}$ at $298 \mathrm{~K}$ and the white precipitate formed during the reaction was filtered off. The resulting colourless filtrate was concentrated to $10 \mathrm{~mL}$ under reduced pressure, and the solution was layered by addition of $5 \mathrm{~mL}$ of hexane (b.p. $40-60{ }^{\circ} \mathrm{C}$ ) to yield colourless microcrystals. Yield: $0.140 \mathrm{~g}(93 \%) . \mathrm{C}_{30} \mathrm{H}_{36} \mathrm{~F}_{6} \mathrm{~N}_{3} \mathrm{P}_{3} \mathrm{Pd}$ (751.9): calcd. C 47.93, H 4.79, N 5.59; found C 47.56, H 4.88, N 5.53. m.p. $191-194{ }^{\circ} \mathrm{C}$ (dec.). Major endo,syn,trans isomer (3a): ${ }^{1} \mathrm{H}$ NMR (400 MHz, $\left.\mathrm{CD}_{3} \mathrm{COCD}_{3}\right): \delta=1.41\left(\mathrm{~d},{ }^{3} J_{\mathrm{H}, \mathrm{H}}=6.5 \mathrm{~Hz}, \mathrm{CH}_{3}\right.$ $\left.\mathrm{CHMe}_{2}\right), 1.66\left(\mathrm{~d},{ }^{3} J_{\mathrm{H}, \mathrm{H}}=6.6 \mathrm{~Hz}, \mathrm{CH}_{3} \mathrm{CHMe}_{2}\right), 1.74$ (merged with allyl- $\mathrm{CH}_{3}$ signal of isomer $\left.3 \mathbf{b}, \mathrm{H}_{\mathrm{a}}{ }^{\prime}\right), 1.79\left(\mathrm{dd},{ }^{4} J_{\mathrm{H}, \mathrm{P}}=11.6,{ }^{3} J_{\mathrm{H}, \mathrm{H}}=\right.$ $6.4 \mathrm{~Hz}$, allyl- $\mathrm{CH}_{3}$ ), 2.20 (merged with solvent signal, 3- $\mathrm{CH}_{3}$ $\left.\mathrm{N}_{2} \mathrm{C}_{3} \mathrm{HMe}_{2}-3,5\right), 2.86$ (s, 5- $\left.\mathrm{CH}_{3} \mathrm{~N}_{2} \mathrm{C}_{3} \mathrm{HMe}_{2}-3,5\right), 3.11\left(\mathrm{~m}, \mathrm{H}_{\mathrm{a}}\right.$ ), 3.30 $\left(\mathrm{d},{ }^{3} J_{\mathrm{H}, \mathrm{H}}=6.6 \mathrm{~Hz}, \mathrm{H}_{\mathrm{s}}{ }^{\prime}\right), 4.12(\mathrm{~m}, \mathrm{CH} \mathrm{CHMe}), 5.76\left(\mathrm{~m}, \mathrm{H}_{\mathrm{c}}\right), 6.61$ (br. s, $\mathrm{CH} \mathrm{N} \mathrm{C}_{2} \mathrm{HMe}_{2}-3,5$ ), 7.16-8.48 (m, aryl protons) ppm. ${ }^{13} \mathrm{C}$ NMR [100.6 MHz, $\mathrm{CDCl}_{3}$ and $\left.\mathrm{CH}_{2} \mathrm{Cl}_{2}(1: 1)\right]: \delta=13.1\left(\mathrm{~d},{ }^{3} J_{\mathrm{C}, \mathrm{P}}=\right.$ $\left.5.6 \mathrm{~Hz}, \mathrm{CH}_{3} \mathrm{~N}_{2} \mathrm{C}_{3} \mathrm{HMe}_{2}-3,5\right), 14.8$ (s, $\left.\mathrm{CH}_{3} \mathrm{~N}_{2} \mathrm{C}_{3} \mathrm{HMe}_{2}-3,5\right), 18.7$ (br. s, allyl- $\left.\mathrm{CH}_{3}\right), 25.3\left(\mathrm{~s}, \mathrm{CH}_{3} \mathrm{CHMe}_{2}\right), 25.5\left(\mathrm{~d},{ }^{3} J_{\mathrm{C}, \mathrm{P}}=9.0 \mathrm{~Hz}\right.$, $\mathrm{CH}_{3} \mathrm{CHMe}_{2}$ ), 52.8 (dd, ${ }^{2} J_{\mathrm{C}, \mathrm{P}}=28.05$ and $6.5 \mathrm{~Hz}, \mathrm{CH} \mathrm{CHMe} 2$ ), 110.1 (s, $\left.\mathrm{CH} \mathrm{N} \mathrm{C}_{3} \mathrm{HMe}_{2}-3,5\right), 129.5-157.2$ (aryl carbon atoms) ppm. exo,syn,trans isomer (3b): ${ }^{1} \mathrm{H}$ NMR $\left(400 \mathrm{MHz}, \mathrm{CD}_{3} \mathrm{COCD}_{3}\right)$ : $\delta=1.12\left(\mathrm{~d},{ }^{3} J_{\mathrm{H}, \mathrm{H}}=6.4 \mathrm{~Hz}, \mathrm{CH}_{3} \mathrm{CHMe}_{2}\right), 1.39\left(\mathrm{~d},{ }^{3} J_{\mathrm{H}, \mathrm{H}}=6.6 \mathrm{~Hz}\right.$, $\left.\mathrm{CH}_{3} \mathrm{CHMe}_{2}\right), 1.69\left(\mathrm{dd},{ }^{4} J_{\mathrm{H}, \mathrm{P}}=11.7,{ }^{3} J_{\mathrm{H}, \mathrm{H}}=6.8 \mathrm{~Hz}\right.$, allyl- $\left.\mathrm{CH}_{3}\right)$, 2.69 (s, 3- $\left.\mathrm{CH}_{3} \mathrm{~N}_{2} \mathrm{C}_{3} \mathrm{HMe}_{2}-3,5\right), 2.73\left(\mathrm{~d},{ }^{3} \mathrm{~J}_{\mathrm{H}, \mathrm{H}}=6.7 \mathrm{~Hz}, \mathrm{H}_{\mathrm{s}}{ }^{\prime}\right), 2.88$ (s, 5- $\left.\mathrm{CH}_{3} \mathrm{~N}_{2} \mathrm{C}_{3} \mathrm{HMe}_{2}-3,5\right), 2.92\left(\mathrm{~d},{ }^{3} J_{\mathrm{H}, \mathrm{H}}=12.1 \mathrm{~Hz}, \mathrm{H}_{\mathrm{a}}{ }^{\prime}\right), 4.25(\mathrm{~m}$, $\mathrm{H}_{\mathrm{c}}$ ), $4.91\left(\mathrm{~m}, \mathrm{H}_{\mathrm{a}}\right.$ ), 6.81 (br. s, $\left.\mathrm{CH} \mathrm{N} \mathrm{C}_{3} \mathrm{HMe}_{2}-3,5\right)$ ppm. ${ }^{13} \mathrm{C} \mathrm{NMR}$ [100.6 MHz, $\mathrm{CDCl}_{3}$ and $\left.\mathrm{CH}_{2} \mathrm{Cl}_{2}(1: 1)\right]: \delta=13.3\left(\mathrm{~d},{ }^{3} J_{\mathrm{C}, \mathrm{P}}=6.5\right.$, $\mathrm{CH}_{3} \mathrm{~N}_{2} \mathrm{C}_{3} \mathrm{HMe}_{2}-3,5$ ), 14.6 (s, $\mathrm{CH}_{3} \mathrm{~N}_{2} \mathrm{C}_{3} \mathrm{HMe}_{2}-3,5$ ), 17.7 (br. s, allyl- $\left.\mathrm{CH}_{3}\right), 24.6\left(\mathrm{~d},{ }^{2} J_{\mathrm{C}, \mathrm{P}}=16.6 \mathrm{~Hz}, \mathrm{CH}_{3} \mathrm{CHMe}_{2}\right), 24.3\left(\mathrm{~d},{ }^{2} J_{\mathrm{C}, \mathrm{P}}=\right.$ $19.4 \mathrm{~Hz}, \mathrm{Me} \mathrm{CHMe}_{2}$ ), 110.0 (s, CH N $\left.\mathrm{C}_{3} \mathrm{HMe}_{2}-3,5\right) \mathrm{ppm}$.

The following complexes were synthesised in a way similar to that used for the preparation of complex 3 .

$\left[\mathrm{Pd}\left(\eta^{3}-1-\mathrm{MeC}_{3} \mathrm{H}_{4}\right)\left\{\eta^{2}-(S R)-\mathrm{Ph}_{2} \mathrm{PN}[(S)-* \mathrm{CHMePh}] \mathrm{PPh}-\right.\right.$ $\left.\left.\left(\mathbf{N}_{2} \mathbf{C}_{3} \mathbf{H M e}_{2}-\mathbf{3 , 5}\right)\right\}\right]\left(\mathbf{P F}_{\mathbf{6}}\right) \quad$ (4): Starting materials: $\left[\mathrm{Pd}\left(\eta^{3}-1-\right.\right.$ $\left.\left.\mathrm{MeC}_{3} \mathrm{H}_{4}\right)(\mu-\mathrm{Cl})\right]_{2} \quad\left(0.039 \mathrm{~g}, \quad 0.99 \cdot 10^{-4} \mathrm{~mol}\right), \mathrm{NH}_{4} \mathrm{PF}_{6}(0.033 \mathrm{~g}$, $\left.2.02 \cdot 10^{-4} \mathrm{~mol}\right)$, and $\mathbf{1 b}\left(0.105 \mathrm{~g}, 2.07 \cdot 10^{-4} \mathrm{~mol}\right)$. Colourless crystals of 4 were grown from acetone solution by layering with hexane (b.p. $\left.40-60{ }^{\circ} \mathrm{C}\right)$. Yield: $0.130 \mathrm{~g}(80 \%)$; m.p. $140-142{ }^{\circ} \mathrm{C}$ dec. $\mathrm{C}_{35} \mathrm{H}_{38} \mathrm{~F}_{6} \mathrm{~N}_{3} \mathrm{P}_{3} \mathrm{Pd}$ (814.0): calcd. C 51.66, H 4.67, N 5.16; found $\mathrm{C}$ 51.37, H 4.59, N 5.11. Major, endo,syn,trans isomer (4a): ${ }^{1} \mathrm{H}$ NMR $\left(500 \mathrm{MHz}, \mathrm{CDCl}_{3}\right): \delta=1.46$ (merged with allyl- $\mathrm{CH}_{3}$ signal of isomer $\left.4 \mathbf{b}, \mathrm{H}_{\mathrm{a}}{ }^{\prime}\right), 1.54\left(\mathrm{dd},{ }^{4} J_{\mathrm{H}, \mathrm{P}}=11.2,{ }^{3} J_{\mathrm{H}, \mathrm{H}}=6.4 \mathrm{~Hz}\right.$, allyl- $\left.\mathrm{CH}_{3}\right)$, $1.72\left(\mathrm{~s}, 3-\mathrm{CH}_{3} \mathrm{~N}_{2} \mathrm{C}_{3} \mathrm{HMe}_{2}-3,5\right), 1.87\left[\mathrm{~d},{ }^{3} \mathrm{~J}_{\mathrm{H}, \mathrm{H}}=6.9 \mathrm{~Hz}, \mathrm{CH}_{3}(S)-*\right.$ $\mathrm{CHMePh}$ ], 2.76 (merged with 5- $\mathrm{CH}_{3} \mathrm{~N}_{2} \mathrm{C}_{3} \mathrm{HMe}_{2}-3,5$ signal, $\mathrm{H}_{\mathrm{a}}$ ), $2.77\left(\mathrm{~s}, 5-\mathrm{CH}_{3} \mathrm{~N}_{2} \mathrm{C}_{3} \mathrm{HMe}_{2}-3,5\right), 3.01\left(\mathrm{~d},{ }^{3} J_{\mathrm{H}, \mathrm{H}}=6.5 \mathrm{~Hz}, \mathrm{H}_{\mathrm{s}}{ }^{\prime}\right), 4.65$ $\left[\mathrm{m}, \mathrm{CH}(S)-{ }^{*} \mathrm{CHMePh}\right], 5.35\left(\mathrm{~m}, \mathrm{H}_{\mathrm{c}}\right), 6.22\left(\mathrm{~d},{ }^{4} J_{\mathrm{H}, \mathrm{P}}=1.7 \mathrm{~Hz}, \mathrm{CH}\right.$ $\mathrm{N}_{2} \mathrm{C}_{3} \mathrm{HMe}_{2}-3,5$ ), 6.52-7.81 (m, aryl protons) ppm. ${ }^{13} \mathrm{C} \mathrm{NMR}$ $\left(125.7 \mathrm{MHz}, \mathrm{CDCl}_{3}\right): \delta=13.7\left(\mathrm{~s}, \mathrm{CH}_{3} \mathrm{~N}_{2} \mathrm{C}_{3} \mathrm{HMe}_{2}-3,5\right), 14.6$ (s, $\mathrm{CH}_{3} \quad \mathrm{~N}_{2} \mathrm{C}_{3} \mathrm{HMe}_{2}-3,5$ ), 18.9 (br. s, allyl- $\mathrm{CH}_{3}$ ), 25.1 [d, ${ }^{3} J_{\mathrm{C}, \mathrm{P}}=$ $22.2 \mathrm{~Hz}, \mathrm{CH}_{3}(S)-{ }^{*} \mathrm{CHMePh}$ ], 60.3 [m, CH $\left.(S)-{ }^{*} \mathrm{CHMePh}\right], 110.5$ (s, $\mathrm{CH} \mathrm{N} \mathrm{C}_{3} \mathrm{HMe}_{2}-3,5$ ), 126.3-157.2 (aryl carbon atoms). exo,syn,trans isomer (4b): ${ }^{1} \mathrm{H}$ NMR $\left(500 \mathrm{MHz}, \mathrm{CDCl}_{3}\right): \delta=1.45$ (merged with $\mathrm{H}_{\mathrm{a}}{ }^{\prime}$ of isomer $4 \mathrm{a}$, allyl- $\left.\mathrm{CH}_{3}\right), 1.45\left(\mathrm{dd},{ }^{4} J_{\mathrm{H}, \mathrm{P}}=10.7,{ }^{3} J_{\mathrm{H}, \mathrm{H}}=\right.$ $6.0 \mathrm{~Hz}$, allyl- $\left.\mathrm{CH}_{3}\right), 1.70\left[\mathrm{~d},{ }^{3} J_{\mathrm{H}, \mathrm{H}}=7.3 \mathrm{~Hz}, \mathrm{CH}_{3}(S)-{ }^{*} \mathrm{CHMePh}\right.$, $2.08\left(\mathrm{~s}, 3-\mathrm{CH}_{3} \mathrm{~N}_{2} \mathrm{C}_{3} \mathrm{HMe}_{2}-3,5\right), 2.46\left(\mathrm{~d},{ }^{3} J_{\mathrm{H}, \mathrm{H}}=11.9 \mathrm{~Hz}, \mathrm{H}_{\mathrm{a}}{ }^{\prime}\right), 2.75$ (s, 5- $\mathrm{CH}_{3} \mathrm{~N}_{2} \mathrm{C}_{3} \mathrm{HMe}_{2}-3,5$ ), 2.77 (merged with 5- $\mathrm{CH}_{3} \mathrm{~N}_{2} \mathrm{C}_{3} \mathrm{HMe}_{2}-$ 3,5 signal, $\left.\mathrm{H}_{\mathrm{s}}{ }^{\prime}\right), 4.05\left(\mathrm{~m}, \mathrm{H}_{\mathrm{c}}\right), 4.40\left(\mathrm{~m}, \mathrm{H}_{\mathrm{a}}\right), 6.34\left(\mathrm{~d},{ }^{4} J_{\mathrm{H}, \mathrm{P}}=2.3 \mathrm{~Hz}\right.$, $\left.\mathrm{CH} \mathrm{N} \mathrm{C}_{3} \mathrm{HMe}_{2}-3,5\right)$ ppm. ${ }^{13} \mathrm{C} \mathrm{NMR}\left(125.7 \mathrm{MHz}, \mathrm{CDCl}_{3}\right): \delta=$ 13.8 (s, $\left.\mathrm{CH}_{3} \mathrm{~N}_{2} \mathrm{C}_{3} \mathrm{HMe}_{2}-3,5\right), 14.9$ (s, $\left.\mathrm{CH}_{3} \mathrm{~N}_{2} \mathrm{C}_{3} \mathrm{HMe}_{2}-3,5\right), 17.9$ (br. s, allyl- $\left.\mathrm{CH}_{3}\right), 24.8\left[\mathrm{~d},{ }^{3} J_{\mathrm{C}, \mathrm{P}}=21.1 \mathrm{~Hz}, \mathrm{CH}_{3}(\mathrm{~S})-{ }^{*} \mathrm{CHMePh}\right.$, 110.6 (s, $\left.\mathrm{CH} \mathrm{N}_{2} \mathrm{C}_{3} \mathrm{HMe}_{2}-3,5\right) \mathrm{ppm}$. endo,syn,cis isomer $(\mathbf{4 c}):{ }^{1} \mathrm{H}$ $\operatorname{NMR}\left(500 \mathrm{MHz}, \mathrm{CDCl}_{3}\right): \delta=0.97\left(\mathrm{t},{ }^{3} J_{\mathrm{H}, \mathrm{H}}={ }^{4} J_{\mathrm{H}, \mathrm{P}}=6.5 \mathrm{~Hz}\right.$, allyl- $\left.\mathrm{CH}_{3}\right), 1.75\left(\mathrm{~s}, 3-\mathrm{CH}_{3} \mathrm{~N}_{2} \mathrm{C}_{3} \mathrm{HMe}_{2}-3,5\right), 1.92\left[\mathrm{~d},{ }^{3} J_{\mathrm{H}, \mathrm{H}}=7.1 \mathrm{~Hz}\right.$, $\mathrm{CH}_{3}(\mathrm{~S})-{ }^{*} \mathrm{CHMePh}$, 2.06 (merged with $3-\mathrm{CH}_{3} \mathrm{~N}_{2} \mathrm{C}_{3} \mathrm{HMe}_{2}-3,5$ signal of isomer $\left.4 \mathbf{b}, \mathrm{H}_{\mathrm{a}}\right), 2.59\left(\mathrm{~m}, \mathrm{H}_{\mathrm{a}}{ }^{\prime}\right), 2.74$ (merged with $5-\mathrm{CH}_{3}$ $\mathrm{N}_{2} \mathrm{C}_{3} \mathrm{HMe}_{2}-3,5$ signal of isomer $\left.4 \mathrm{a}, 5-\mathrm{CH}_{3} \mathrm{~N}_{2} \mathrm{C}_{3} \mathrm{HMe}_{2}-3,5\right), 4.65$ [merged with $\mathrm{CH}(S)-{ }^{*} \mathrm{CHMePh}$ signal, $\mathrm{H}_{\mathrm{s}}$ ], 5.35 (merged with $\mathrm{H}_{\mathrm{c}}$ signal of isomer $\left.4 \mathrm{a}, \mathrm{H}_{\mathrm{c}}\right)$ ppm. ${ }^{13} \mathrm{C} \mathrm{NMR}\left(125.7 \mathrm{MHz}, \mathrm{CDCl}_{3}\right): \delta=$ 17.4 (s, allyl- $\left.\mathrm{CH}_{3}\right) \mathrm{ppm}$.

$\left[\mathrm{Pd}\left(\eta^{3}-1-\mathrm{PhC}_{3} \mathrm{H}_{4}\right)\left\{\eta^{2}-\mathrm{Ph}_{2} \mathrm{PN}\left(\mathrm{CHMe}_{2}\right) \mathrm{PPh}\left(\mathrm{N}_{2} \mathrm{C}_{3} \mathrm{HMe}_{2}-3,5\right)\right\}\right]\left(\mathrm{PF}_{6}\right)$ (5): Starting materials: $\left[\mathrm{Pd}\left(\eta^{3}-1-\mathrm{PhC}_{3} \mathrm{H}_{4}\right)(\mu-\mathrm{Cl})\right]_{2} \quad(0.052 \mathrm{~g}$, $\left.1.00 \cdot 10^{-4} \mathrm{~mol}\right), \mathrm{NH}_{4} \mathrm{PF}_{6}\left(0.033 \mathrm{~g}, 2.02 \cdot 10^{-4} \mathrm{~mol}\right)$, and $1 \mathrm{a}(0.095 \mathrm{~g}$, $\left.2.13 \cdot 10^{-4} \mathrm{~mol}\right)$. Yellow crystals of 5 were obtained by layering with hexane (b.p. $\left.40-60{ }^{\circ} \mathrm{C}\right)$. Yield: $0.135 \mathrm{~g}(83 \%)$; m.p. $193-196{ }^{\circ} \mathrm{C}$ (dec.). $\mathrm{C}_{35} \mathrm{H}_{38} \mathrm{~F}_{6} \mathrm{~N}_{3} \mathrm{P}_{3} \mathrm{Pd}$ (814.0): calcd. C 51.66, H 4.67, N 5.16; 
found $\mathrm{C}$ 51.48, $\mathrm{H}$ 4.88, $\mathrm{N}$ 5.17. endo,syn,trans isomer $(\mathbf{5 a}):{ }^{1} \mathrm{H}$ NMR (400 MHz, $\mathrm{CDCl}_{3}$ ): $\delta=0.96$ (s, 3- $\left.\mathrm{CH}_{3} \mathrm{~N}_{2} \mathrm{C}_{3} \mathrm{HMe}_{2}-3,5\right), 1.13$ $\left(\mathrm{d},{ }^{3} J_{\mathrm{H}, \mathrm{H}}=6.5 \mathrm{~Hz}, \mathrm{CH}_{3} \mathrm{CHMe}_{2}\right) ; 1.20\left(\mathrm{~d},{ }^{3} J_{\mathrm{H}, \mathrm{H}}=6.4 \mathrm{~Hz}, \mathrm{CH}_{3}\right.$ $\left.\mathrm{CHMe}_{2}\right), 1.74\left(\mathrm{~d},{ }^{3} J_{\mathrm{H}, \mathrm{H}}=11.6 \mathrm{~Hz}, \mathrm{H}_{\mathrm{a}}{ }^{\prime}\right), 2.60$ (s, 5- $\mathrm{CH}_{3}$ $\left.\mathrm{N}_{2} \mathrm{C}_{3} \mathrm{HMe}_{2}-3,5\right), 3.17\left(\mathrm{dd},{ }^{3} J_{\mathrm{H}, \mathrm{H}}=6.8,{ }^{3} J_{\mathrm{H}, \mathrm{P}}=1.7 \mathrm{~Hz}, \mathrm{H}_{\mathrm{s}}{ }^{\prime}\right), 3.73$ $(\mathrm{m}, \mathrm{CH} \mathrm{CHMe}), 3.97\left(\mathrm{dd},{ }^{3} J_{\mathrm{H}, \mathrm{H}}=13.5,{ }^{3} J_{\mathrm{H}, \mathrm{P}}=11.3 \mathrm{~Hz}, \mathrm{H}_{\mathrm{a}}\right)$, $6.01\left(\mathrm{~d},{ }^{4} J_{\mathrm{H}, \mathrm{P}}=2.1 \mathrm{~Hz}, \mathrm{CH} \mathrm{N}_{2} \mathrm{C}_{3} \mathrm{HMe}_{2}-3,5\right), 6.12\left(\mathrm{~m}, \mathrm{H}_{\mathrm{c}}\right)$, 6.85-7.71 (m, aryl protons) ppm. ${ }^{13} \mathrm{C}$ NMR (100.6 $\mathrm{MHz}, \mathrm{CDCl}_{3}$ ): $\delta=13.3\left(\mathrm{~s}, \mathrm{CH}_{3} \mathrm{~N}_{2} \mathrm{C}_{3} \mathrm{HMe}_{2}-3,5\right), 13.8\left(\mathrm{~d},{ }^{3} J_{\mathrm{C}, \mathrm{P}}=17.8 \mathrm{~Hz}, \mathrm{CH}_{3}\right.$ $\left.\mathrm{N}_{2} \mathrm{C}_{3} \mathrm{HMe}_{2}-3,5\right), 24.9\left(\mathrm{~d},{ }^{3} J_{\mathrm{C}, \mathrm{P}}=17.8 \mathrm{~Hz}, \mathrm{CH}_{3} \mathrm{CHMe}_{2}\right), 26.1(\mathrm{~d}$, $\left.{ }^{3} J_{\mathrm{C}, \mathrm{P}}=9.1 \mathrm{~Hz}, \mathrm{CH}_{3} \mathrm{CHMe}_{2}\right), 53.4\left(\mathrm{dd},{ }^{2} J_{\mathrm{C}, \mathrm{P}}=27.9\right.$ and $6.1 \mathrm{~Hz}$, $\mathrm{CH} \mathrm{CHMe}$ ), 110.1 (s, $\left.\mathrm{CH} \mathrm{N}_{2} \mathrm{C}_{3} \mathrm{HMe}_{2}-3,5\right), 127.7-158.7$ (aryl carbon atoms). exo,syn,trans isomer (5b): ${ }^{1} \mathrm{H}$ NMR $(400 \mathrm{MHz}$, $\left.\mathrm{CDCl}_{3}\right): \delta=2.11\left(\mathrm{~s}, 3-\mathrm{Me} \mathrm{N} \mathrm{N}_{2} \mathrm{C}_{3} \mathrm{HMe}_{2}-3,5\right), 2.52$ (s, 5- $\mathrm{CH}_{3}$ $\mathrm{N}_{2} \mathrm{C}_{3} \mathrm{HMe}_{2}-3,5$ ), 2.59 (merged with 5- $\mathrm{CH}_{3} \mathrm{~N}_{2} \mathrm{C}_{3} \mathrm{HMe}_{2}-3,5$ signal of isomer $5 \mathrm{a}, \mathrm{H}_{\mathrm{s}}{ }^{\prime}$ ), 2.61 (merged with $5-\mathrm{CH}_{3} \mathrm{~N}_{2} \mathrm{C}_{3} \mathrm{HMe}_{2}-3,5$ signal of isomer 5a, $\left.\mathrm{H}_{\mathrm{a}}{ }^{\prime}\right), 4.88\left(\mathrm{~m}, \mathrm{H}_{\mathrm{c}}\right), 5.50\left(\mathrm{t},{ }^{3} J_{\mathrm{H}, \mathrm{H}}={ }^{3} J_{\mathrm{H}, \mathrm{P}}=12.5 \mathrm{~Hz}\right.$, $\mathrm{H}_{\mathrm{a}}$ ), 6.17 (merged with $\mathrm{H}_{\mathrm{c}}$ signal of isomer 5a, $\mathrm{CH} \mathrm{N} \mathrm{C}_{3} \mathrm{HMe}_{2}-$ 3,5). endo,syn, cis isomer (5c) ${ }^{1} \mathrm{H}$ NMR $\left(400 \mathrm{MHz}, \mathrm{CDCl}_{3}\right): \delta=$ $2.05\left(\mathrm{~s}, 3-\mathrm{CH}_{3} \mathrm{~N}_{2} \mathrm{C}_{3} \mathrm{HMe}_{2}-3,5\right), 2.37\left(\mathrm{dd},{ }^{3} J_{\mathrm{H}, \mathrm{H}}=12.5,{ }^{3} J_{\mathrm{H}, \mathrm{P}}=\right.$ $\left.10.0 \mathrm{~Hz}, \mathrm{H}_{\mathrm{a}}\right), 2.62\left(\mathrm{~s}, 5-\mathrm{CH}_{3} \mathrm{~N}_{2} \mathrm{C}_{3} \mathrm{HMe}_{2}-3,5\right), 3.29\left(\mathrm{~d},{ }^{3} J_{\mathrm{H}, \mathrm{H}}=\right.$ $\left.12.0 \mathrm{~Hz}, \mathrm{H}_{\mathrm{a}}{ }^{\prime}\right), 4.80\left(\mathrm{t},{ }^{3} J_{\mathrm{H}, \mathrm{H}}={ }^{3} J_{\mathrm{H}, \mathrm{P}}=7.5 \mathrm{~Hz}, \mathrm{H}_{\mathrm{s}}\right), 5.91\left(\mathrm{~m}, \mathrm{H}_{\mathrm{c}}\right)$, 6.29 (br., $\mathrm{CH} \mathrm{N}_{2} \mathrm{C}_{3} \mathrm{HMe}_{2}-3,5$ ) ppm.

$\left[\mathrm{Pd}\left(\eta^{3}-1-\mathrm{PhC}_{3} \mathrm{H}_{4}\right)\left\{\eta^{2}-(S R)-\mathrm{Ph}_{2} \mathrm{PN}[(S)-* \mathrm{CHMePh}] \mathrm{PPh}-\right.\right.$ $\left.\left.\left.\mathbf{N}_{\mathbf{2}} \mathbf{C}_{\mathbf{3}} \mathbf{H M e}_{2} \mathbf{- 3}, \mathbf{5}\right)\right\}\right]\left(\mathbf{P F}_{\mathbf{6}}\right) \quad$ (6): Starting materials: $\left[\mathrm{Pd}\left(\eta^{3}-1-\right.\right.$ $\left.\left.\mathrm{PhC}_{3} \mathrm{H}_{4}\right)(\mu-\mathrm{Cl})\right]_{2} \quad\left(0.052 \mathrm{~g}, 1.00 \cdot 10^{-4} \mathrm{~mol}\right), \mathrm{NH}_{4} \mathrm{PF}_{6} \quad(0.033 \mathrm{~g}$, $\left.2.02 \cdot 10^{-4} \mathrm{~mol}\right)$, and $\mathbf{1 b}\left(0.105 \mathrm{~g}, 2.07 \cdot 10^{-4} \mathrm{~mol}\right)$. Isolation of the title compound in a pure form was unsuccessful. endo,syn,trans isomer (6a): ${ }^{1} \mathrm{H}$ NMR $\left(400 \mathrm{MHz}, \mathrm{CDCl}_{3}\right): \delta=0.73$ (s, 3- $\mathrm{CH}_{3}$ $\left.\mathrm{N}_{2} \mathrm{C}_{3} \mathrm{HMe}_{2}-3,5\right), 1.74\left(\mathrm{~d},{ }^{3} J_{\mathrm{H}, \mathrm{H}}=12.9 \mathrm{~Hz}, \mathrm{H}_{\mathrm{a}}{ }^{\prime}\right), 1.84\left[\mathrm{~d},{ }^{3} J_{\mathrm{H}, \mathrm{H}}=\right.$ $6.9 \mathrm{~Hz}, \mathrm{CH}_{3}(S)-{ }^{*} \mathrm{CHMePh}$, $2.73\left(\mathrm{~s}, 5-\mathrm{CH}_{3} \mathrm{~N}_{2} \mathrm{C}_{3} \mathrm{HMe}_{2}-3,5\right), 3.22$ $\left(\mathrm{d},{ }^{3} J_{\mathrm{H}, \mathrm{H}}=6.9 \mathrm{~Hz}, \mathrm{H}_{\mathrm{s}}{ }^{\prime}\right), 3.92\left(\mathrm{t},{ }^{3} J_{\mathrm{H}, \mathrm{H}}={ }^{3} J_{\mathrm{H}, \mathrm{P}}=12.3 \mathrm{~Hz}, \mathrm{H}_{\mathrm{a}}\right)$, $4.63\left[\mathrm{~m}, \mathrm{CH}(S)-{ }^{*} \mathrm{CHMePh}\right], 5.96\left(\mathrm{~d},{ }^{4} J_{\mathrm{H}, \mathrm{P}}=2.1 \mathrm{~Hz}, \mathrm{CH}\right.$ $\left.\mathrm{N}_{2} \mathrm{C}_{3} \mathrm{HMe}_{2}-3,5\right), 6.08\left(\mathrm{~m}, \mathrm{H}_{\mathrm{c}}\right), 6.65-7.68$ (m, aryl protons) ppm. ${ }^{13} \mathrm{C} \mathrm{NMR}\left(100.6 \mathrm{MHz}, \mathrm{CDCl}_{3}\right): \delta=12.5\left(\mathrm{~s}, \mathrm{CH}_{3} \mathrm{~N}_{2} \mathrm{C}_{3} \mathrm{HMe}_{2}-3,5\right)$, $13.5\left(\mathrm{~d},{ }^{3} J_{\mathrm{C}, \mathrm{P}}=18.2 \mathrm{~Hz}, \mathrm{CH}_{3} \mathrm{~N}_{2} \mathrm{C}_{3} \mathrm{HMe}_{2}-3,5\right), 24.8\left[\mathrm{~d},{ }^{3} J_{\mathrm{C}, \mathrm{P}}=\right.$ $\left.22.9 \mathrm{~Hz}, \mathrm{CH}_{3}(S)-{ }^{*} \mathrm{CHMePh}\right], 60.2\left[\mathrm{dd},{ }^{2} J_{\mathrm{C}, \mathrm{P}}=24.1\right.$ and $6.3 \mathrm{~Hz}$, $\left.\mathrm{CH}(S)-{ }^{*} \mathrm{CHMePh}\right], 110.2\left(\mathrm{~s}, \mathrm{CH} \mathrm{N} \mathrm{C}_{3} \mathrm{HMe}_{2}-3,5\right), 126.6-158.3$ (aryl carbon atoms). exo,syn,trans isomer $(\mathbf{6 b})$ : ${ }^{1} \mathrm{H} \quad \mathrm{NMR}$ (400 MHz, $\mathrm{CDCl}_{3}$ ): $\delta=2.11$ (s, 3- $\left.\mathrm{CH}_{3} \mathrm{~N}_{2} \mathrm{C}_{3} \mathrm{HMe}_{2}-3,5\right), 2.52$ (s, 5$\mathrm{CH}_{3} \mathrm{~N}_{2} \mathrm{C}_{3} \mathrm{HMe}_{2}-3,5$ ), 2.71 (merged with 5- $\mathrm{CH}_{3} \mathrm{~N}_{2} \mathrm{C}_{3} \mathrm{HMe}_{2}-3,5$ of isomer $\left.6 \mathrm{a}, \mathrm{H}_{\mathrm{a}}{ }^{\prime}\right), 2.82\left(\mathrm{br} ., \mathrm{H}_{\mathrm{s}}{ }^{\prime}\right), 4.81\left(\mathrm{~m}, \mathrm{H}_{\mathrm{c}}\right), 5.41\left(\mathrm{dd},{ }^{3} J_{\mathrm{H}, \mathrm{H}}=13.6\right.$, ${ }^{3} J_{\mathrm{H}, \mathrm{P}}=11.2 \mathrm{~Hz}, \mathrm{H}_{\mathrm{a}}$ ), 5.99 (br. s, $\mathrm{CH} \mathrm{N}_{2} \mathrm{C}_{3} \mathrm{HMe}_{2}-3,5$ ). endo,syn, cis isomer (6c): ${ }^{1} \mathrm{H}$ NMR (400 MHz, $\mathrm{CDCl}_{3}$ ): $\delta=2.21$ (br. t, $\mathrm{H}_{\mathrm{a}}$ ), 3.20 (merged with $\mathrm{H}_{\mathrm{s}}{ }^{\prime}$ of isomer $\left.6 \mathrm{a}, \mathrm{H}_{\mathrm{a}}{ }^{\prime}\right), 4.75\left(\mathrm{t},{ }^{3} J_{\mathrm{H}, \mathrm{H}}={ }^{3} J_{\mathrm{H}, \mathrm{P}}=\right.$ $\left.7.2 \mathrm{~Hz}, \mathrm{H}_{\mathrm{s}}\right), 5.83\left(\mathrm{~m}, \mathrm{H}_{\mathrm{c}}\right) \mathrm{ppm}$.

$\left[\operatorname{Pd}\left(\eta^{3}-1-\mathrm{MeC}_{3} \mathrm{H}_{4}\right)\left\{\eta^{2}-\mathrm{Ph}_{2} \mathrm{P}(\mathrm{S}) \mathbf{N}\left(\mathrm{CHMe}_{2}\right) \mathbf{P P h}\left(\mathrm{N}_{2} \mathrm{C}_{3} \mathrm{HMe}_{2}-\right.\right.\right.$ 3,5)\}] $\mathbf{P F}_{\mathbf{6}}$ (7): Starting materials: $\left[\mathrm{Pd}\left(\eta^{3}-1-\mathrm{MeC}_{3} \mathrm{H}_{4}\right)(\mu-\mathrm{Cl})\right]_{2}$ $\left(0.039 \mathrm{~g}, 0.99 \cdot 10^{-4} \mathrm{~mol}\right), \mathrm{NH}_{4} \mathrm{PF}_{6}\left(0.033 \mathrm{~g}, 2.02 \cdot 10^{-4} \mathrm{~mol}\right)$, and $1 \mathrm{c}$ $\left(0.100 \mathrm{~g}, 2.09 \cdot 10^{-4} \mathrm{~mol}\right)$. Colourless crystals of 7 were obtained by layering with hexane (b.p. $40-60{ }^{\circ} \mathrm{C}$ ). Yield: $0.133 \mathrm{~g}(85 \%)$; m.p. $178-180{ }^{\circ} \mathrm{C}$ (dec.). $\mathrm{C}_{30} \mathrm{H}_{36} \mathrm{~F}_{6} \mathrm{~N}_{3} \mathrm{P}_{3} \mathrm{PdS}$ (784.0): calcd. C 45.97, $\mathrm{H}$ 4.59, N 5.36; found $\mathrm{C} 45.95, \mathrm{H} 4.41, \mathrm{~N}$ 5.24. endo,syn,trans isomer (7a): ${ }^{1} \mathrm{H} \mathrm{NMR}\left(500 \mathrm{MHz}, \mathrm{CDCl}_{3}\right): \delta=0.41\left(\mathrm{~d},{ }^{3} J_{\mathrm{H}, \mathrm{H}}=6.9 \mathrm{~Hz}\right.$, $\mathrm{CH}_{3} \mathrm{CHMe}_{2}$ ), $1.10\left(\mathrm{~d},{ }^{3} \mathrm{~J}_{\mathrm{H}, \mathrm{H}}=6.1 \mathrm{~Hz}, \mathrm{CH}_{3} \mathrm{CHMe}_{2}\right.$ ), 1.95 (merged with 5- $\mathrm{CH}_{3} \mathrm{~N}_{2} \mathrm{C}_{3} \mathrm{HMe}_{2}-3,5$ signal, allyl- $\mathrm{CH}_{3}$ ), 2.40 (merged with 3- $\mathrm{CH}_{3} \mathrm{~N}_{2} \mathrm{C}_{3} \mathrm{HMe}_{2}-3,5$ signal, $\left.\mathrm{H}_{\mathrm{a}}{ }^{\prime}\right), 3.97\left(\mathrm{~d},{ }^{3} J_{\mathrm{H}, \mathrm{H}}=6.1 \mathrm{~Hz}, \mathrm{H}_{\mathrm{s}}{ }^{\prime}\right)$, 4.60 (merged with $\mathrm{CH} \mathrm{CHMe} 2$ signal, $\mathrm{H}_{\mathrm{a}}$ ), $5.40\left(\mathrm{~m}, \mathrm{H}_{\mathrm{c}}\right.$ ), 6.16 (br. s, $\left.\mathrm{CH} \mathrm{N} \mathrm{C}_{3} \mathrm{HMe}_{2}-3,5\right), 7.19-7.96$ (m, aryl protons) ppm. ${ }^{13} \mathrm{C} \mathrm{NMR}$ $\left(100.6 \mathrm{MHz}, \mathrm{CDCl}_{3}\right): \delta=12.2\left(\mathrm{~s}, \mathrm{CH}_{3} \mathrm{~N}_{2} \mathrm{C}_{3} \mathrm{HMe}_{2}-3,5\right), 13.6$ (s, $\mathrm{CH}_{3} \quad \mathrm{~N}_{2} \mathrm{C}_{3} \mathrm{HMe}_{2}-3,5$ ), 18.3 (br. s, allyl- $\mathrm{CH}_{3}$ ), 22.9 (d, ${ }^{3} J_{\mathrm{C}, \mathrm{P}}=$ $20.4 \mathrm{~Hz}, \mathrm{CH}_{3} \mathrm{CHMe}_{2}$ ), 23.1 (d, ${ }^{3} J_{\mathrm{C}, \mathrm{P}}=15.2 \mathrm{~Hz}, \mathrm{CH}_{3} \mathrm{CHMe}_{2}$ ),
57.8 (br. s, $\mathrm{CH} \quad \mathrm{CHMe}_{2}$ ), 110.7 (s, $\mathrm{CH} \quad \mathrm{N}_{2} \mathrm{C}_{3} \mathrm{HMe}_{2}-3,5$ ), 128.2-155.6 (aryl carbon atoms). exo,syn,trans isomer $(7 \mathbf{b}):{ }^{1} \mathrm{H}$ NMR (500 MHz, $\mathrm{CDCl}_{3}$ ): $\delta=2.15\left(\mathrm{~s}, 5-\mathrm{CH}_{3} \mathrm{~N}_{2} \mathrm{C}_{3} \mathrm{HMe}_{2}-3,5\right), 1.96$ (merged with allyl- $\mathrm{CH}_{3}$ signal of isomer 7a, allyl- $\mathrm{CH}_{3}$ ), 2.91 (d, $\left.{ }^{3} J_{\mathrm{H}, \mathrm{H}}=12.0 \mathrm{~Hz}, \mathrm{H}_{\mathrm{a}}{ }^{\prime}\right), 3.52\left(\mathrm{~d},{ }^{3} J_{\mathrm{H}, \mathrm{H}}=6.4 \mathrm{~Hz}, \mathrm{H}_{\mathrm{s}}{ }^{\prime}\right), 4.46$ (br. t, $\left.{ }^{3} J_{\mathrm{H}, \mathrm{H}}=7.6 \mathrm{~Hz}, \mathrm{H}_{\mathrm{a}}\right), 5.49\left(\mathrm{~m}, \mathrm{H}_{\mathrm{c}}\right) \mathrm{ppm} .{ }^{13} \mathrm{C} \mathrm{NMR}(100.6 \mathrm{MHz}$, $\mathrm{CDCl}_{3}$ ): $\delta=18.3$ (merged with allyl- $\mathrm{CH}_{3}$ signal of isomer 7a, allyl$\left.\mathrm{CH}_{3}\right)$. endo,syn, cis isomer (7c): ${ }^{1} \mathrm{H}$ NMR $\left(500 \mathrm{MHz}, \mathrm{CDCl}_{3}\right): \delta=$ $1.32\left(\mathrm{dd},{ }^{4} J_{\mathrm{H}, \mathrm{P}}=9.5,{ }^{3} J_{\mathrm{H}, \mathrm{H}}=6.5 \mathrm{~Hz}\right.$, allyl- $\left.\mathrm{CH}_{3}\right), 2.02\left(\mathrm{~s}, 5-\mathrm{CH}_{3}\right.$ $\left.\mathrm{N}_{2} \mathrm{C}_{3} \mathrm{HMe}_{2}-3,5\right), 3.37\left(\mathrm{~m}, \mathrm{H}_{\mathrm{a}}\right), 3.65\left(\mathrm{~m}, \mathrm{H}_{\mathrm{a}}{ }^{\prime}\right), 4.46$ (merged with $\mathrm{H}_{\mathrm{a}}$ signal of isomer $\mathbf{7 b}, \mathrm{H}_{\mathrm{s}}$ ), 5.42 (merged with $\mathrm{H}_{\mathrm{c}}$ signal of isomer $\mathbf{7 a}$, $\mathrm{H}_{\mathrm{c}}$ ) ppm. ${ }^{13} \mathrm{C} \mathrm{NMR}\left(100.6 \mathrm{MHz}, \mathrm{CDCl}_{3}\right): \delta=17.2$ (br. s, allyl$\mathrm{CH}_{3}$ ). exo,syn,cis isomer (7d): ${ }^{1} \mathrm{H} \mathrm{NMR}\left(500 \mathrm{MHz}, \mathrm{CDCl}_{3}\right): \delta=$ 0.98 (br. t, ${ }^{3} J_{\mathrm{H}, \mathrm{H}}={ }^{4} J_{\mathrm{H}, \mathrm{P}}=6.6 \mathrm{~Hz}$, allyl- $\left.\mathrm{CH}_{3}\right), 2.10\left(\mathrm{~s}, \mathrm{CH}_{3}\right.$ $\mathrm{N}_{2} \mathrm{C}_{3} \mathrm{HMe}_{2}-3,5$ ), 3.37 (merged with $\mathrm{H}_{\mathrm{a}}$ signal of isomer $7 \mathrm{c}, \mathrm{H}_{\mathrm{a}}$ ), 4.02 (br. s, $\mathrm{H}_{\mathrm{a}}{ }^{\prime}$ ), 4.63 (merged with $\mathrm{CH} \mathrm{CHMe} 2$ signal, $\mathrm{H}_{\mathrm{s}}$ ), 5.38 (merged with $\mathrm{H}_{\mathrm{c}}$ signal of isomer $7 \mathbf{a}, \mathrm{H}_{\mathrm{c}}$ ) ppm. ${ }^{13} \mathrm{C} \mathrm{NMR}$ $\left(100.6 \mathrm{MHz}, \mathrm{CDCl}_{3}\right): \delta=17.5$ (br. s, allyl- $\mathrm{CH}_{3}$ ). endo, anti,trans isomer (7e): ${ }^{1} \mathrm{H}$ NMR $\left(500 \mathrm{MHz}, \mathrm{CDCl}_{3}\right.$ ): $\delta=0.76$ (br. d, allyl$\mathrm{CH}_{3}$ ), 2.80 (d, $\left.\mathrm{H}_{\mathrm{a}}{ }^{\prime}\right), 3.73$ (br. s, $\mathrm{H}_{\mathrm{s}}$ ), 4.15 (br. d, $\left.\mathrm{H}_{\mathrm{s}}{ }^{\prime}\right), 5.30$ (m, $\mathrm{H}_{\mathrm{c}}$ ). endo,anti,cis isomer (7f): ${ }^{1} \mathrm{H} \mathrm{NMR}\left(500 \mathrm{MHz}, \mathrm{CDCl}_{3}\right): \delta=0.27(\mathrm{t}$, allyl- $\mathrm{CH}_{3}$ ), 3.72 (merged with $\mathrm{H}_{\mathrm{s}}$ signal of isomer $7 \mathrm{e}, \mathrm{H}_{\mathrm{a}}$ ), 4.66 (merged with $\mathrm{CH} \mathrm{CHMe} 2$ signal, $\mathrm{H}_{\mathrm{s}}$ ), $5.05\left(\mathrm{~m}, \mathrm{H}_{\mathrm{s}}{ }^{\prime}\right), 5.29$ (merged with $\mathrm{H}_{\mathrm{c}}$ signal of isomer $7 \mathrm{e}, \mathrm{H}_{\mathrm{c}}$ ).

$\left[\mathrm{Pd}\left(\boldsymbol{\eta}^{3}-1-\mathrm{PhC}_{3} \mathrm{H}_{4}\right)\left\{\boldsymbol{\eta}^{2}-\mathrm{Ph}_{2} \mathrm{P}(\mathrm{S}) \mathbf{N}\left(\mathrm{CHMe}_{2}\right) \mathrm{PPh}\left(\mathrm{N}_{2} \mathrm{C}_{3} \mathrm{HMe}_{2}-3,5\right)\right\}\right]-$ (PF $\mathbf{P F}_{6}$ (8): Starting materials: $\left[\mathrm{Pd}\left(\eta^{3}-1-\mathrm{PhC}_{3} \mathrm{H}_{4}\right)(\mu-\mathrm{Cl})\right]_{2}(0.052 \mathrm{~g}$, $\left.1.00 \cdot 10^{-4} \mathrm{~mol}\right), \mathrm{NH}_{4} \mathrm{PF}_{6}\left(0.033 \mathrm{~g}, 2.02 \cdot 10^{-4} \mathrm{~mol}\right)$, and $\mathbf{1 c}(0.100 \mathrm{~g}$, $\left.2.09 \cdot 10^{-4} \mathrm{~mol}\right)$. Yellow crystals were obtained by layering with hexane (b.p. $40-60{ }^{\circ} \mathrm{C}$ ). Yield: $0.142 \mathrm{~g}(84 \%)$; m.p. $171-174{ }^{\circ} \mathrm{C}$ (dec.). $\mathrm{C}_{35} \mathrm{H}_{38} \mathrm{~F}_{6} \mathrm{~N}_{3} \mathrm{P}_{3} \mathrm{PdS}$ (846.1): calcd. C 49.70, H 4.49, N 4.97; found $\mathrm{C} 49.62, \mathrm{H}$ 4.55, N 4.65. endo,syn,trans isomer (8a): ${ }^{1} \mathrm{H} \mathrm{NMR}$ (400 MHz, $\mathrm{CDCl}_{3}$ ): $\delta=0.39$ (br. s, $\mathrm{CH}_{3} \mathrm{CHMe}_{2}$ ), 1.19 (br. s, $\mathrm{CH}_{3}$ $\left.\mathrm{CHMe}_{2}\right), \quad 2.05 \quad\left(\mathrm{~s}, \quad 5-\mathrm{CH}_{3} \quad \mathrm{~N}_{2} \mathrm{C}_{3} \mathrm{HMe}_{2}-3,5\right), \quad 2.37 \quad$ (s, 3- $\mathrm{CH}_{3}$ $\mathrm{N}_{2} \mathrm{C}_{3} \mathrm{HMe}_{2}-3,5$ ), 2.79 (br. s, $\mathrm{H}_{\mathrm{a}}{ }^{\prime}$ ), 4.23 (br. s, $\mathrm{H}_{\mathrm{s}}{ }^{\prime}$ ), 4.61 (br., $\mathrm{CH}$ $\mathrm{CHMe}_{2}$ ), 5.63 (br., $\mathrm{H}_{\mathrm{a}}$ ), 6.04 (br., $\mathrm{H}_{\mathrm{c}}$ ), 6.28 (br. s, $\mathrm{CH} \mathrm{N} \mathrm{C}_{2} \mathrm{HMe}_{2}-$ 3,5), 6.52-7.98 (m, aryl protons) ppm. ${ }^{13} \mathrm{C}$ NMR $[100.6 \mathrm{MHz}$, $\mathrm{CDCl}_{3}$ and $\left.\mathrm{CH}_{2} \mathrm{Cl}_{2}(1: 1)\right]: \delta=13.5\left(\mathrm{~s}, \mathrm{CH}_{3} \mathrm{~N}_{2} \mathrm{C}_{3} \mathrm{HMe}_{2}-3,5\right), 13.9$ (br., $\mathrm{CH}_{3} \mathrm{~N}_{2} \mathrm{C}_{3} \mathrm{HMe}_{2}-3,5$ ), 23.0 (s, $\mathrm{CH}_{3} \mathrm{CHMe}_{2}$ ), 58.0 (br., $\mathrm{CH}$ $\mathrm{CHMe}_{2}$ ), 110.8 (s, $\mathrm{CH} \mathrm{N} \mathrm{C}_{3} \mathrm{HMe}_{2}-3,5$ ), 126.0-155.7 (aryl carbon atoms). exo,syn,trans isomer (8b): ${ }^{1} \mathrm{H} \mathrm{NMR}\left(400 \mathrm{MHz}, \mathrm{CDCl}_{3}\right)$ : $\delta=3.23$ (br. $\mathrm{s}, \mathrm{H}_{\mathrm{a}}{ }^{\prime}$ ), 3.77 (br., $\mathrm{H}_{\mathrm{s}}{ }^{\prime}$ ), 5.49 (br. $\mathrm{H}_{\mathrm{a}}$ ), 6.11 (br., $\mathrm{H}_{\mathrm{c}}$ ). endo,syn,cis isomer (8c): ${ }^{1} \mathrm{H}$ NMR $\left(400 \mathrm{MHz}, \mathrm{CDCl}_{3}\right): \delta=3.70$ (br., $\mathrm{H}_{\mathrm{a}}$ ), 4.68 (br. t, $\mathrm{H}_{\mathrm{s}}$ ), 4.73 (br. $\mathrm{d}, \mathrm{H}_{\mathrm{a}}{ }^{\prime}$ ), 6.18 (br., $\mathrm{H}_{\mathrm{c}}$ ). exo,syn, cis isomer (8d): ${ }^{1} \mathrm{H}$ NMR (400 MHz, $\mathrm{CDCl}_{3}$ ): $\delta=3.69$ (br., $\mathrm{H}_{\mathrm{a}}$ ), 4.79 (br., $\mathrm{H}_{\mathrm{s}}$ ), 5.00 (br. d, $\left.\mathrm{H}_{\mathrm{a}}{ }^{\prime}\right), 6.00\left(\mathrm{~m}, \mathrm{H}_{\mathrm{c}}\right)$ ppm.

X-ray Crystallography: Crystal data for complex 5a were collected by using a Siemens SMART CCD diffractometer. The crystallographic data and details on data collection are summarised in Table 3. The structure was solved by direct methods, using the program SIR-97[24] and refined on $F^{2}$ values for all unique data by full-matrix, least squares by using SHELXTL. ${ }^{[25]}$ The non-hydrogen atoms were refined anisotropically. The hydrogen atoms were fixed at their calculated geometrical positions and refined isotropically. CCDC-172846 contains the supplementary crystallographic data for this paper. These data can be obtained free of charge at www.ccdc.cam.ac.uk/conts/retrieving.html or from the Cambridge Crystallographic Data Centre, 12, Union Road, Cambridge CB2 1EZ, UK [Fax: (internat.) + 44-1223/336-033; E-mail: deposit@ccdc.cam.ac.uk].

\section{Acknowledgments}

We thank the Department of Science and Technology (DST), New Delhi for financial support. 
Table 3. Crystal data and structure refinement for complex 5a

\begin{tabular}{ll}
\hline Empirical formula & $\mathrm{C}_{35} \mathrm{H}_{38} \mathrm{~F}_{6} \mathrm{P}_{3} \mathrm{~N}_{3} \mathrm{Pd}$ \\
Formula mass & 813.99 \\
Temperature & $293(2) \mathrm{K}$ \\
Wavelength & $0.71073 \AA$ \\
Crystal system & monoclinic \\
Space group & $P 2_{1}$ \\
Unit cell dimensions & $a=9.8783(8) \AA$ \\
& $b=18.1125(14) \AA$ \\
& $c=10.2360(8) \AA$ \\
Volume & $\beta=97.223(2)^{\circ}$ \\
$Z$ & $1816.9(2) \AA^{3}$ \\
Density (calculated) & 2 \\
Absorption coefficient & $1.488 \mathrm{Mg} / \mathrm{m}^{3}$ \\
$F(000)$ & $0.703 \mathrm{~mm}{ }^{-1}$ \\
Crystal size & 828 \\
$\theta$ range for data collection & $0.12 \times 0.06 \times 0.06 \mathrm{~mm}$ \\
Index ranges & $2.01-23.28^{\circ}$. \\
& $-10 \leq h \leq 10,-20 \leq k \leq 20$, \\
Reflections collected & $-11 \leq l \leq 9$ \\
Independent reflections & 8238 \\
Completeness to $\theta=23.28^{\circ}$ & $4817[R($ int $)=0.0275]$ \\
Refinement method & $99.7 \%$ \\
Data/restraints/parameters & full-matrix, least squares on $F^{2}$ \\
Goodness-of-fit on $F^{2}$ & $4817 / 1 / 435$ \\
Final $R$ indices $[I>2 \sigma(I)]$ & 1.140 \\
$R$ indices (all data) & $R 1=0.0740, w R 2=0.1785$ \\
Absolute structure parameter & $R 1=0.1058, w R 2=0.2102$ \\
Extinction coefficient & $0.00(7)$ \\
Largest diff. peak and hole & $0.0055(13)$ \\
& 2.298 and $-0.676 \mathrm{e} \cdot \AA^{-3}$ \\
&
\end{tabular}

${ }^{[1]}{ }^{[1 \mathrm{a}]}$ B. M. Trost, T. R. Verhoeven, in: Comprehensive Organometallic Chemistry (Eds.: G. Wilkinson, F. G. A. Stone, E. W. Abel), Pergamon Press, Oxford, 1982, vol. 8, p. 799. ${ }^{[1 b]}$ P. Von Matt, A. Pfaltz, Angew. Chem. Int. Ed. Engl. 1993, 32, 566. [1c] T. Hayashi, in: Catalytic Asymmetric Synthesis (Ed.: I. Ojima), $\mathrm{VCH}$, New York, 1993, p. 325 and references cited therein. [1d] R. Noyori, Asymmetric Catalysis in Organic Synthesis, Wiley, New York, 1994, p. 82. ${ }^{[1 \mathrm{e}]}$ B. M. Trost, D. L. van Vranken, Chem. Rev. 1996, 96, 395. [1f] G. Consiglio, R. M. Waymouth, Chem. Rev. 1989, 89, 257. ${ }^{[1 \mathrm{~g}]}$ C. G. Frost, J. Howarth, J. M. J. Williams, Tetrahedron: Asymmetry 1992, 3, 1089. ${ }^{[1 \mathrm{~h}]} \mathrm{G}$. Helmchen, J. Organomet. Chem. 1999, 576, 203.

[2] [2a] A. Pfaltz, Acta Chim. Scand. B 1996, 50, 189 and references there in. ${ }^{[2 b]}$ S. Kudis, G. Helmchen, Angew. Chem. Int. Ed. 1998, 37, 3047. ${ }^{[2 c] ~ G . ~ J . ~ D a w s o n, ~ G . ~ F r o s t, ~ J . ~ M . ~ J . ~ W i l l i a m s, ~}$ Tetrahedron Lett. 1993, 34, 3149. [2d] G. Helmchen, S. Kudis, P. Sennhenn, H. Steinhagen, Pure Appl. Chem. 1997, 69, 513 and references therein.

[3] [3a] D. A. Evans, K. R. Campos, J. S. Tedrow, F. E. Michael, M. R. Gagné, J. Org. Chem. 1999, 64, 2994. ${ }^{[3 b]}$ D. A. Evans, K. R. Campos, J. S. Tedrow, F. E. Michael, M. R. Gagné, J. Am. Chem. Soc. 2000, 122, 7905. ${ }^{[3 c]}$ K. Selvakumar, M. Valentini, P. S. Pregosin, A. Albinati, Organometallics 1999, 18, 4591. [3d] A. Albinati, P. S. Pregosin, K. Wick, Organometallics 1996, 15, 2419. ${ }^{[3 \mathrm{e}]}$ A. Albinati, J. Eckert, P. S. Pregosin, H. Rüegger, R. Salzmann, C. Stössel, Organometallics 1997, 16, 579.

${ }^{[4]}\left[{ }^{4 a]}\right.$ T. Morimoto, K. Tachibana, K. Achiwa, Synlett 1997, 783. [4b] J. C. Anderson, D. S. James, J. P. Mathias, Tetrahedron: Asymmetry 1998, 9, 753. ${ }^{[4 \mathrm{c}]} \mathrm{J}$. Allen, J. Bower, J. Williams, Tetrahedron: Asymmetry 1994, 5, 1895. ${ }^{[4 \mathrm{~d}]} \mathrm{K}$. Boog-Wick, P. S. Pregosin, G. Trabesinger, Organometallics 1998, 17, 3254.

[5] B. M. Trost, F. D. Toste, J. Am. Chem. Soc. 1999, 121, 4545.

[6] G. Helmchen, A. Pfaltz, Acc. Chem. Res. 2000, 33, 336.

[7] [7a] P. S. Pregosin, R. Salzmann, Coord. Chem. Rev. 1996, 155,
35. [7b] P.S. Pregosin, G. Trabesinger, J. Chem. Soc., Dalton Trans. 1998, 727. ${ }^{[7 c]}$ J. M. Canal, M. Gómez, F. Jiménez, M. Rocamora, G. Muller, E. Duñach, D. Franco, A. Jiménez, F. H. Cano, Organometallics 2000, 19, 966. [7d] A. Gogoll, C. Johansson, A. Axén, H. Grennberg, Chem. Eur. J. 2001, 7, 396.

[8] [8a] M. Ganesan, S. S. Krishnamurthy, M. Nethaji, J. Organomet. Chem. 1998, 570, 247. ${ }^{[8 b]}$ R. P. K. Babu, K. Aparna, S. S. Krishnamurthy, M. Nethaji, Phosphorus, Sulfur Silicon 1995, 103, 39. ${ }^{[8 c]}$ M. Ganesan, S. S. Krishnamurthy, M. Nethaji, K. Raghuraman, Phosphorus, Sulfur Silicon 1999, 147, 355. ${ }^{[8 \mathrm{~d}]}$ R. P. K. Babu, S. S. Krishnamurthy, M. Nethaji, Tetrahedron: Asymmetry 1995, 6, 427.

[9] [9a] R. P. K. Babu, S. S. Krishnamurthy, M. Nethaji, Organometallics 1995, 14, 2047. ${ }^{[9 b]}$ R. P. K. Babu, S. S. Krishnamurthy, M. Nethaji, Polyhedron 1996, 15, 2689. ${ }^{[9]}$ R. P. K. Babu, S. S. Krishnamurthy, M. Nethaji, J. Organomet. Chem. 1993, $454,157$.

[10] [10a] M. S. Balakrishna, V. S. Reddy, S. S. Krishnamurthy, J. F. Nixon, J. C. T. R. Burckett St Laurent, Coord. Chem. Rev. 1994, 129, 1. ${ }^{[10 \mathrm{~b}]}$ M. Witt, H. W. Roesky, Chem. Rev. 1994, 94, 1163. ${ }^{[10 c]}$ P. Bhattacharyya, J. D. Woollins, Polyhedron 1995, 14, 3367. ${ }^{[10 \mathrm{~d}]}$ A. M. Z. Slawin, M. B. Smith, J. D. Woollins, J. Chem. Soc., Dalton Trans. 1996, 1283.

[11] [11a] N. Baltzer, L. Macko, S. Schaffner, M. Zehnder, Helv. Chim. Acta 1996, 79, 803. ${ }^{[1 \mathrm{~b}]}$ J. Powell, B. L. Shaw, J. Chem. Soc. A 1967, 1839. ${ }^{[11 \mathrm{c}]}$ B. A kermark, B. Krakenberger, S. Hansson, A. Vitagliano, Organometallics 1987, 6, 620.

[12] [12a] M. L. H. Green, P. L. I. Hagy, Adv. Organomet. Chem. 1964, 2, 325. ${ }^{[12 b]}$ R. Rossch, R. Hoffman, Inorg. Chem. 1974, 13,2656

[13] [13a] A. Togni, U. Burckhardt, V. Gramlich, P. S. Pregosin, R. Salzmann, J. Am. Chem. Soc. 1996, 118, 1031. ${ }^{[13 b]}$ U. Burckhardt, V. Gramlich, P. Hofmann, R. Nesper, P. S. Pregosin, R. Salzmann, A. Togni, Organometallics 1996, 15, 3496. ${ }^{[13 c]}$ T. G. Appleton, H. C. Clark, L. Manzer, Coord. Chem. Rev. 1973, 10,335 .

${ }^{[14]}$ J. W. Faller, M. E. Thomson, M. Mattina, J. Am. Chem. Soc. 1971, 93, 2642.

${ }^{[15]}$ S. K. Mandal, S. S. Krishnamurthy, unpublished results.

${ }^{[16]}$ C. Breutel, P. S. Pregosin, R. Salzmann, A. Togni, J. Am. Chem. Soc. 1994, 116, 4067.

[17] [17a] J. Sprinz, M. Kiefer, G. Helmchen, M. Reggelin, G. Huttner, O. Walter, L. Zsolnai, Tetrahedron Lett. 1994, 35, 1523. ${ }^{[17 b]}$ R. Fernández-Galán, F. A. Jalón, B. R. Manzano, J. R. Fuente, M. Vrahami, B. Jedlicka, W. Weissensteiner, G. Jogl, Organometallics 1997, 16, 3758.

${ }^{[18]}$ J. Hermann, P. S. Pregosin, R. Salzmann, A. Albinati, Organometallics 1995, 14, 3311.

${ }^{[19]}$ T. Hosokawa, Y. Wakabayashi, K. Hosokawa, T. Tsuji, S.-I. Murahashi, Chem. Commun. 1996, 859.

${ }^{[20]}$ B. Crociani, S. Antonaroli, G. Bandoli, L. Canovese, F. Visentin, P. Uguagliati, Organometallics 1999, 18, 1137.

${ }^{[21][21 a]}$ J. M. Brown, D. I. Hulmes, P. J. Guiry, Tetrahedron 1994, 50, 4493. ${ }^{[21 b]}$ S. Hansson, P.-O. Norrby, M. P. T. Sjögren, B. Åkermark, M. E. Cucciolito, F. Giordano, A. Vittagliano, Organometallics 1993, 12, 4940. ${ }^{[21 \mathrm{c}]} \mathrm{U}$. Burckhardt, M. Baumann, G. Trabesinger, V. Gramlich, A. Togni, Organometallics 1997, 16,5252

${ }^{[22]}$ D. D. Perrin, W. L. F. Armarego, D. R. Perrin, Purification of Laboratory Chemicals, 3rd ed., Pergamon Press, Oxford, U. K., 1988

${ }^{[23]}$ P. R. Auburn, P. B. McKenzie, B. Bosnich, J. Am. Chem. Soc. 1985, 107, 2033.

[24] A. Altomare, M.C. Burla, M. Camalli, G. L. Cascarano, C. Giacovazzo, A. Guagliardi, A. G. G. Moliterni, G. Polidori, R. Spagna, J. Appl. Cryst. 1999, 32, 115.

${ }^{[25]}$ G. M. Sheldrick, SHELXTL, Version 5; Bruker AXS Inc.: Madison, Wisconsin, 1997.

Received November 19, 2001

[I01463] 